\title{
LEVEL II SCOUR ANALYSIS FOR BRIDGE 145 (HANCVT01000145) on STATE ROUTE 100, crossing the HANCOCK BRANCH of the WHITE RIVER, HANCOCK, VERMONT
}

U.S. Geological Survey

Open-File Report 96-747

Prepared in cooperation with

VERMONT AGENCY OF TRANSPORTATION

and

FEDERAL HIGHWAY ADMINISTRATION

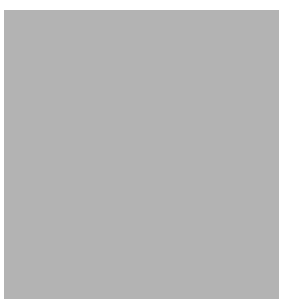




\section{LEVEL II SCOUR ANALYSIS FOR BRIDGE 145 (HANCVT01000145) on STATE ROUTE 100, crossing the HANCOCK BRANCH of the WHITE RIVER, HANCOCK, VERMONT}

By Michael A. Ivanoff and Robert E. Hammond

U.S. Geological Survey

Open-File Report 96-747

Prepared in cooperation with

VERMONT AGENCY OF TRANSPORTATION

and

FEDERAL HIGHWAY ADMINISTRATION

Pembroke, New Hampshire 


\title{
U.S. DEPARTMENT OF THE INTERIOR BRUCE BABBITT, Secretary
}

\author{
U.S. GEOLOGICAL SURVEY \\ Gordon P. Eaton, Director
}

For additional information write to:

District Chief

U.S. Geological Survey 361 Commerce Way

Pembroke, NH 03275-3718
Copies of this report may be purchased from:

U.S. Geological Survey

Branch of Information Services

Open-File Reports Unit

Box 25286

Denver, CO 80225-0286 


\section{CONTENTS}

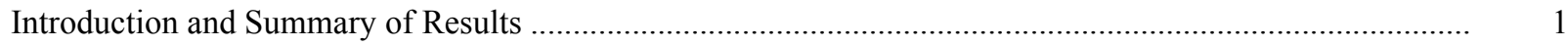

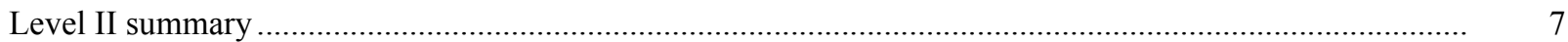

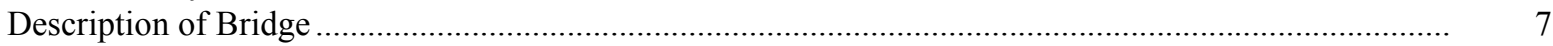

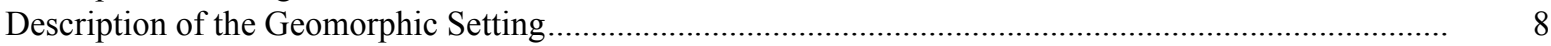

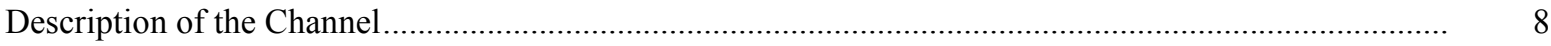

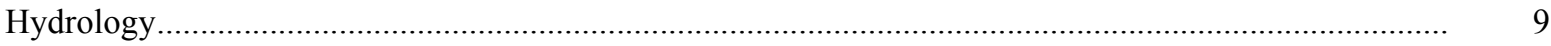

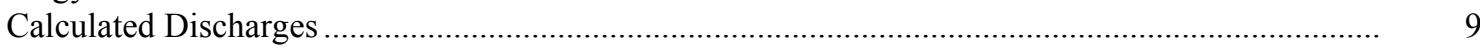

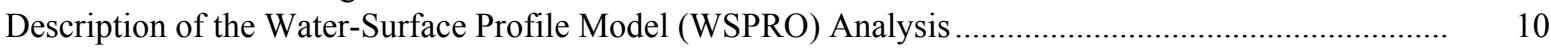

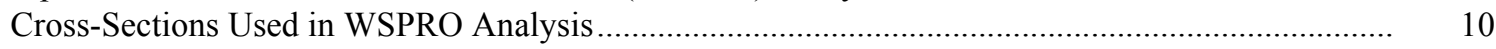

Data and Assumptions Used in WSPRO Model ...................................................................... 11

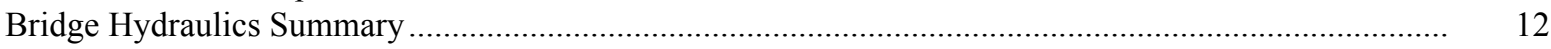

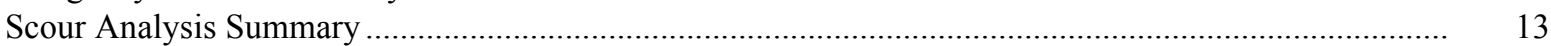

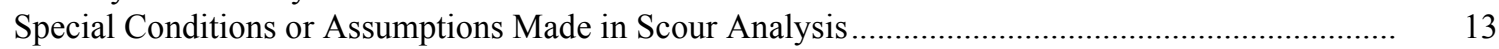

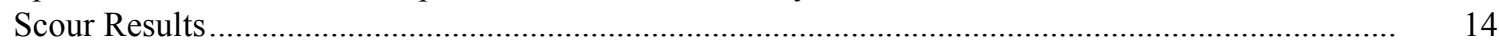

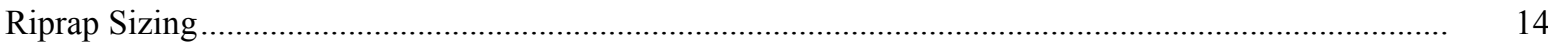

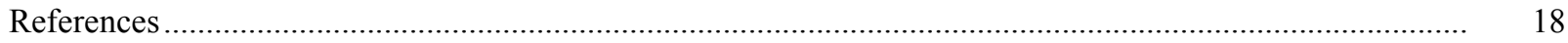

Appendixes:

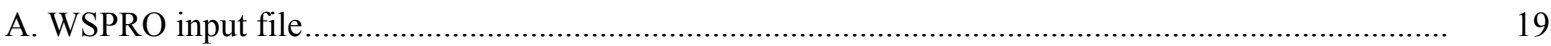

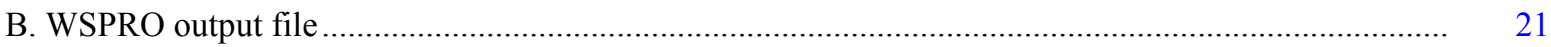

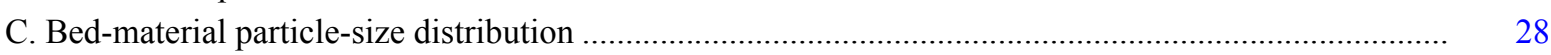

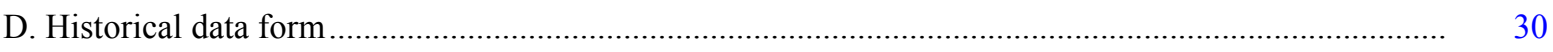

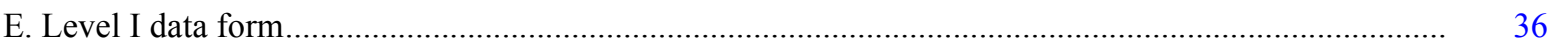

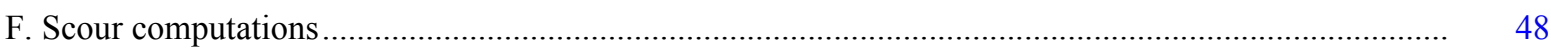

\section{FIGURES}

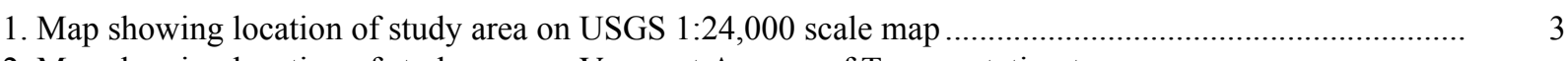

2. Map showing location of study area on Vermont Agency of Transportation town
highway map

3. Structure HANCVT01000145 viewed from upstream (November 16, 1994) ........................................... 5

4. Downstream channel viewed from structure HANCVT01000145 (November 16, 1994)....................... 5

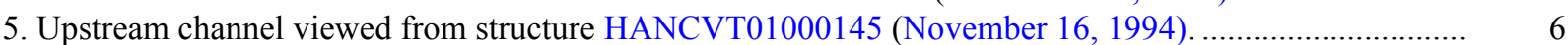

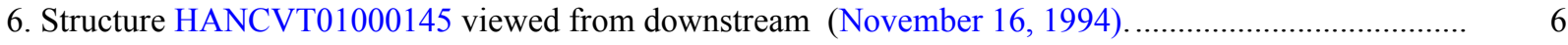

7. Water-surface profiles for the 100- and 500-year discharges at structure

HANCVT01000145 on State Route 100, crossing the Hancock Branch of the White River,

Hancock, Vermont......

8. Scour elevations for the 100- and 500-year discharges at structure

HANCVT01000145 on State Route 100, crossing the Hancock Branch of the White River,

Hancock, Vermont.

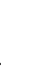

5

6

6




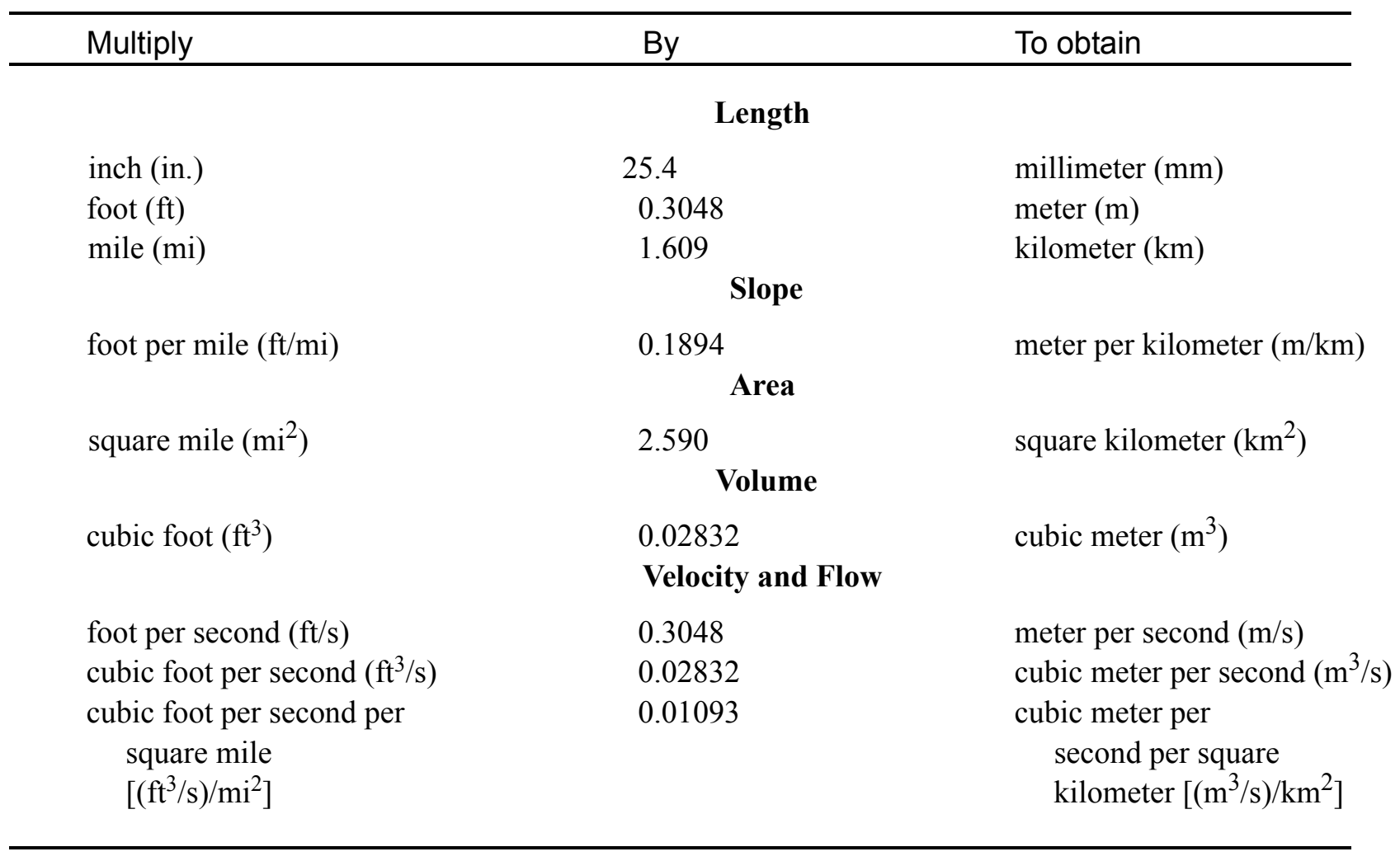

\section{OTHER ABBREVIATIONS}

$\begin{array}{lrlr}\mathrm{BF} & \text { bank full } & \text { LWW } & \text { left wingwall } \\ \mathrm{cfs} & \text { cubic feet per second } & \text { MC } & \text { main channel } \\ \mathrm{D}_{50} & \text { median diameter of bed material } & \text { RAB } & \text { right abutment } \\ \mathrm{DS} & \text { downstream } & \text { RABUT } & \text { face of right abutment } \\ \mathrm{elev} & \text { elevation } & \text { RB } & \text { right bank } \\ \mathrm{f} / \mathrm{p} & \text { flood plain } & \text { ROB } & \text { right overbank } \\ \mathrm{ft}^{2} & \text { square feet } & \text { RWW } & \text { right wingwall } \\ \mathrm{ft} / \mathrm{ft} & \text { feet per foot } & \text { TH } & \text { town highway } \\ \mathrm{JCT} & \text { junction } & \text { UB } & \text { under bridge } \\ \mathrm{LAB} & \text { left abutment } & \text { US } & \text { upstream } \\ \mathrm{LABUT} & \text { face of left abutment } & \text { USGS } & \text { United States Geological Survey } \\ \mathrm{LB} & \text { left bank } & \text { VTAOT Vermont Agency of Transportation } \\ \mathrm{LOB} & \text { left overbank } & \text { WSPRO } & \text { water-surface profile model }\end{array}$

In this report, the words "right" and "left" refer to directions that would be reported by an observer facing downstream. Sea level: In this report, "sea level" refers to the National Geodetic Vertical Datum of 1929-- a geodetic datum derived from a general adjustment of the first-order level nets of the United States and Canada, formerly called Sea Level Datum of 1929.

In the appendices, the above abbreviations may be combined. For example, USLB would represent upstream left bank. 


\title{
LEVEL II SCOUR ANALYSIS FOR BRIDGE 145 (HANCVT01000145) ON STATE ROUTE 100, CROSSING THE HANCOCK BRANCH OF THE WHITE RIVER, HANCOCK, VERMONT
}

\author{
By Michael A. Ivanoff and Robert E. Hammond
}

\section{INTRODUCTION AND SUMMARY OF RESULTS}

This report provides the results of a detailed Level II analysis of scour potential at structure HANCVT01000145 on State Route 100 crossing the Hancock Branch of the White River, Hancock, Vermont (figures 1-8). A Level II study is a basic engineering analysis of the site, including a quantitative analysis of stream stability and scour (U.S. Department of Transportation, 1993). Results of a Level I scour investigation also are included in Appendix E of this report. A Level I investigation provides a qualitative geomorphic characterization of the study site. Information on the bridge, gleaned from Vermont Agency of Transportation (VTAOT) files, was compiled prior to conducting Level I and Level II analyses and is found in Appendix D.

The site is in the Green Mountain section of the New England physiographic province in central Vermont. The 22.0- $\mathrm{mi}^{2}$ drainage area is in a predominantly rural and forested basin. In the vicinity of the study site, the surface cover is urban on left bank and forested on the right bank upstream of the bridge while the immediate banks have woody vegetation. Downstream of the bridge surface cover on both banks is pasture while the immediate banks have woody vegetation.

In the study area, the Hancock Branch of the White River has an incised, sinuous channel with a slope of approximately $0.006 \mathrm{ft} / \mathrm{ft}$, an average channel top width of $48 \mathrm{ft}$ and an average channel depth of $3 \mathrm{ft}$. The predominant channel bed materials are cobble and gravel with a median grain size $\left(\mathrm{D}_{50}\right)$ of $71.9 \mathrm{~mm}(0.236 \mathrm{ft})$. The geomorphic assessment at the time of the Level I and Level II site visit on November 16, 1994, indicated that the reach was stable.

State Route 100 crossing the Hancock Branch of the White River is a 55-ft-long, two-lane bridge consisting of one 53-foot steel-beam span (Vermont Agency of Transportation, written communication, August 26, 1994). The bridge is supported by vertical, concrete abutments with wingwalls. The channel is not skewed to the opening and the opening-skewto-roadway is 0 degrees. 
The only scour protection measures at the site were type- 3 stone fill (less than 48 inches diameter) at the upstream right wingwall, both downstream wingwalls and the downstream ends of both abutments. Also there was type-2 stone fill (less than 36 inches diameter) at the upstream left wingwall. Additional details describing conditions at the site are included in the Level II Summary and Appendices D and E.

Scour depths and rock rip-rap sizes were computed using the general guidelines described in Hydraulic Engineering Circular 18 (Richardson and others, 1995). Total scour at a highway crossing is comprised of three components: 1) long-term streambed degradation; 2) contraction scour (due to accelerated flow caused by a reduction in flow area at a bridge) and; 3) local scour (caused by accelerated flow around piers and abutments). Total scour is the sum of the three components. Equations are available to compute depths for contraction and local scour and a summary of the results of these computations follows.

Contraction scour for all modelled flows ranged from 3.4 to $4.3 \mathrm{ft}$. The worst-case contraction scour occurred at the 500-year discharge. Abutment scour ranged from 8.2 to $11.1 \mathrm{ft}$. The worst-case abutment scour occurred at the 100-year discharge. Additional information on scour depths and depths to armoring are included in the section titled "Scour Results". Scoured-streambed elevations, based on the calculated scour depths, are presented in tables 1 and 2. A cross-section of the scour computed at the bridge is presented in figure 8. Scour depths were calculated assuming an infinite depth of erosive material and a homogeneous particle-size distribution.

It is generally accepted that the Froehlich equation (abutment scour) gives "excessively conservative estimates of scour depths" (Richardson and others, 1995, p. 47). Usually, computed scour depths are evaluated in combination with other information including (but not limited to) historical performance during flood events, the geomorphic stability assessment, existing scour protection measures, and the results of the hydraulic analyses. Therefore, scour depths adopted by VTAOT may differ from the computed values documented herein. 


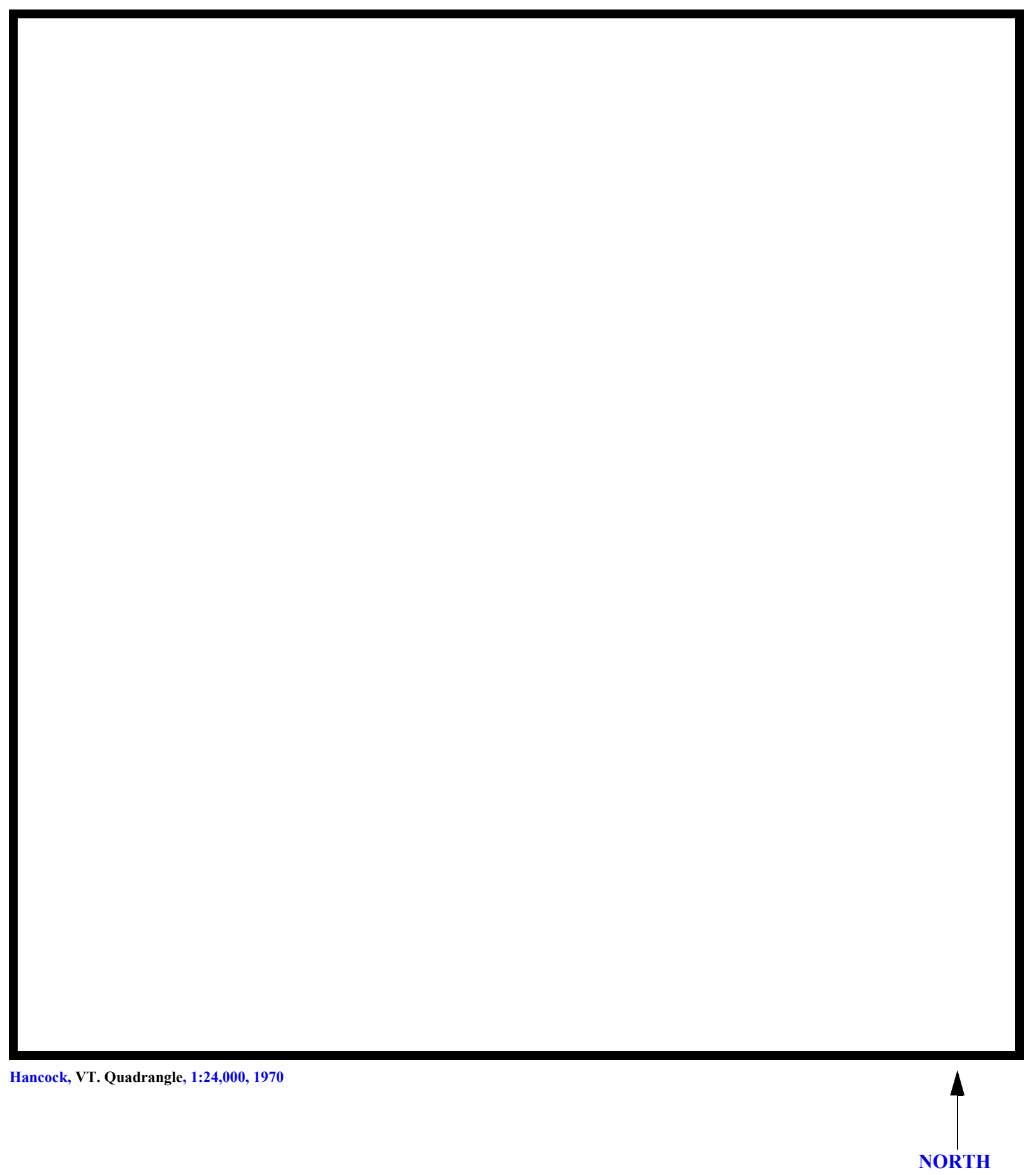

Figure 1. Location of study area on USGS 1:24,000 scale map. 
Figure 2. Location of study area on Vermont Agency of Transportation town highway map. 

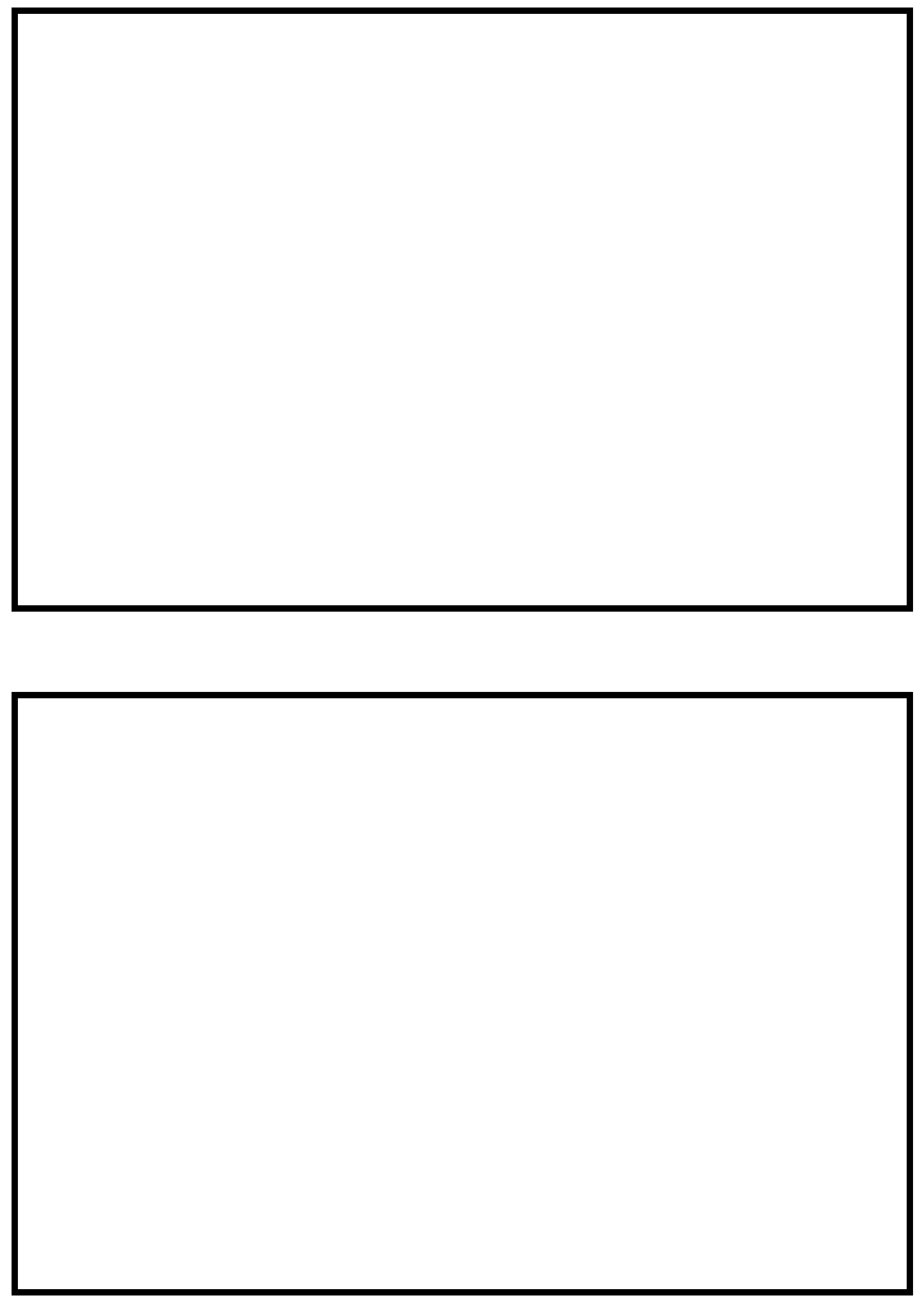

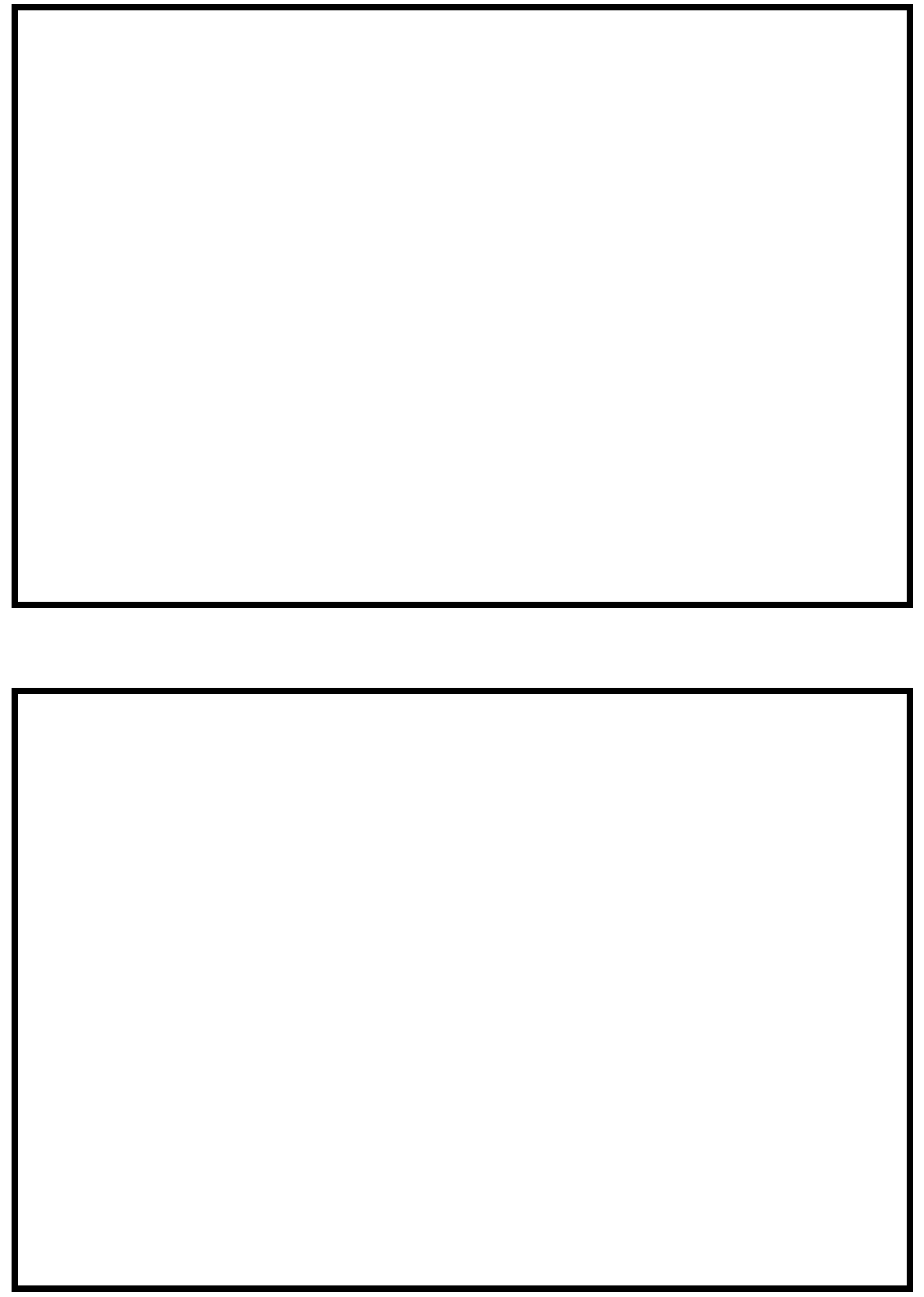


\section{LEVEL II SUMMARY}

\begin{tabular}{llllll} 
Structure Number & HANCVT01000145 & Stream & \multicolumn{2}{l}{ Hancock Branch of the White River } \\
& Road & VT 100 & District & 4
\end{tabular}

\section{Description of Bridge}

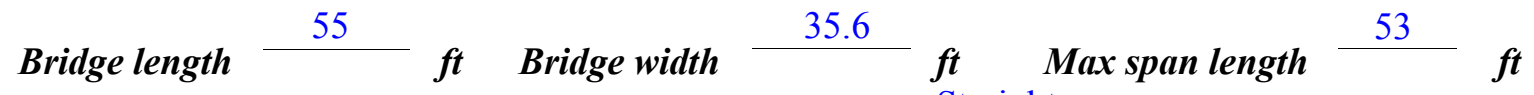
Alignment of bridge to road (on curve or straight)

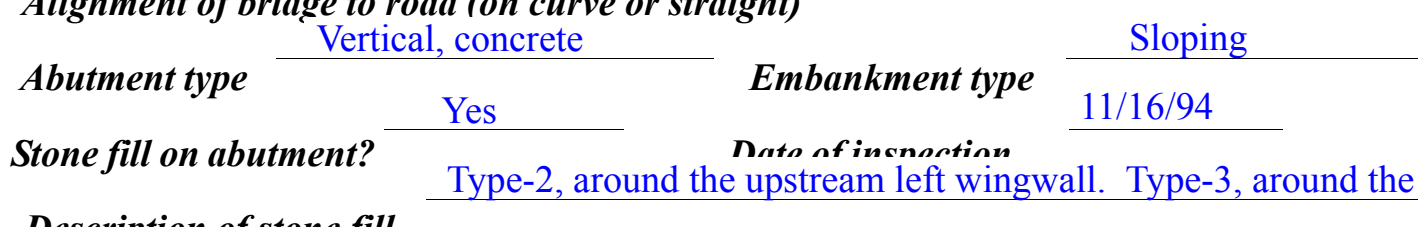
upstream right wingwall, both downstream wingwalls, and the downstream ends of both abutments.

Abutments and wingwalls are concrete.

$\cdots \cdots+\cdots$

$\underline{\text { No }} \quad \underline{0}$

Angle

Debris accumulation on bridge at time of Level I or Level II site visit:

Is bridge skewed to flood flow according to No 'survey?

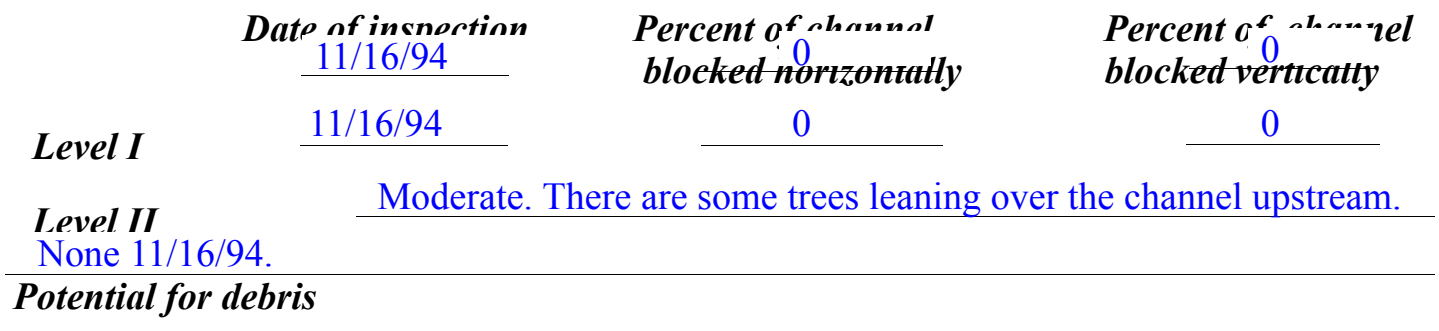

Doscriho any, foaturos noar ar at tho hridoo that mav, affort flou, (includo ahsorvation dato) 


\section{Description of the Geomorphic Setting}

General topography The channel has a flat to slightly irregular flood plain with steep valley

walls on both sides.

Geomorphic conditions at bridge site: downstream (DS), upstream (US)

Date of inspection $\quad 11 / 16 / 94$

DS left: $\quad$ Moderately sloping channel bank to flood plain

DS right: $\quad$ Gradually sloping channel bank to flood plain

US left: $\quad$ Gradually sloping levee to flood plain

US right: $\quad$ Gradually sloping levee to narrow flood plain

\section{Description of the Channel}

\begin{tabular}{|c|c|c|c|}
\hline & 48.0 & & 3.0 \\
\hline Average top width & $\stackrel{f t}{\text { Cobbles/ Gravel }}$ & Average depth & Cobbles/ Gravel \\
\hline
\end{tabular}

Predominant bed material

Bank material Perennial stream with

semi-alluvial to non-alluvial channel boundaries.

$11 / 16 / 94$

Vegetative co ${ }^{1}$ Brush and Trees

DS left: $\quad$ Trees and brush

DS right: $\quad$ Trees

US left: $\quad$ Trees and brush

US right: $\quad$ Yes

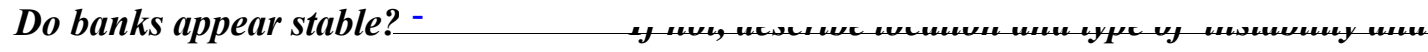

date of observatton.

None, $11 / 16 / 94$

Describe any obstructions in channel and date of observation. 


\section{Hydrology}

Drainage area $\stackrel{22.0}{2} \boldsymbol{m i}^{2}$

Percentage of drainage area in physiographic provinces: (approximate)

Physiographic province/section

New England/Green Mountain
Percent of drainage area 100

Is drainage area considered rural or urban? Rural Describe any significant urbanization: There are buildings and State Route 125 on the upstream left overbank area and some houses on both of the downstream overbanks.

Is there a USGS gage on the stream of interest?

No

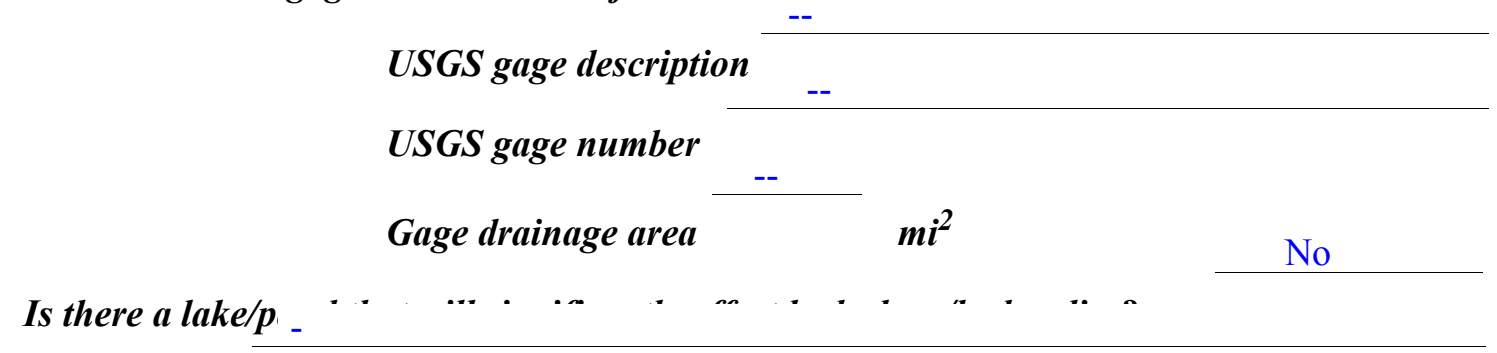

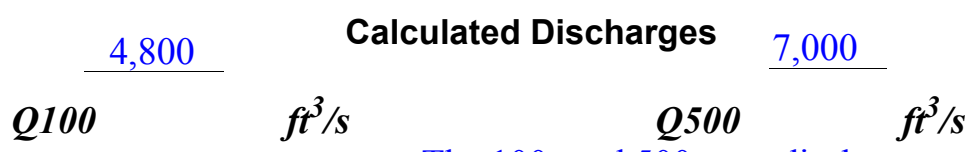

The 100- and 500-year discharges are based on the

Flood Insurance Study for the Town of Hancock, VT (Federal Emergency Management Agency, August 19, 1991). The discharges were within a range defined by frequency curves developed from several empirical methods (Benson, 1962; Johnson and Tasker, 1974; FHWA, 1983; Potter, 1957 a \& b; Talbot, 1987). 


\section{Description of the Water-Surface Profile Model (WSPRO) Analysis}

Datum for WSPRO analysis (USGS survey, sea level, VTAOT plans)

USGS survey

Datum tie between USGS survey and VTAOT plans

Add $414.0 \mathrm{ft}$. to the USGS survey

to obtain VTAOT plans' datum and sea level.

Description of reference marks used to determine USGS datum. $\quad$ RM1 is a brass tablet on

top of the downstream end of the right abutment (elev. $498.00 \mathrm{ft}$, arbitrary survey datum). RM2

is a chiseled X on top of the upstream end of the left abutment (elev. $499.69 \mathrm{ft}$, arbitrary survey

datum).

\begin{tabular}{cccl}
\hline Cross-section & $\begin{array}{c}\text { Section } \\
\text { Reference } \\
\text { Distance } \\
\text { (SRD) } \text { in } \\
\text { feet }\end{array}$ & $\begin{array}{c}{ }^{2} \text { Cross- } \\
\text { section } \\
\text { development }\end{array}$ & \\
\hline EXIT1 & -1058 & 2 & $\begin{array}{l}\text { Comments } \\
\text { River (Templated from ETEMP) }\end{array}$ \\
EXIT2 & -858 & 2 & Downstream Exit section (Templated from ETEMP) \\
EXIT3 & -658 & 2 & Downstream Exit section (Templated from ETEMP) \\
EXIT4 & -458 & 2 & Downstream Exit section (Templated from ETEMP) \\
EXIT5 & -258 & 2 & Downstream Exit section (Templated from ETEMP) \\
EXIT6 & -58 & 2 & Downstream Exit section (Templated from ETEMP) \\
ETEMP & -58 & 1 & Exit section as surveyed (Used as a template) \\
FULLV & 0 & 2 & Downstream Full-valley section (Templated from ETEMP) \\
BRIDG & 0 & 1 & Bridge section \\
RDWAY & 20 & 1 & Road Grade section \\
APPRO & 90 & 2 & Modelled Approach section (Templated from ATEMP) \\
ATEMP & 107 & 1 & Approach section as surveyed (Used as a template) \\
\hline
\end{tabular}

${ }^{1}$ For location of cross-sections see plan-view sketch included with Level I field form, Appendix E. For more detail on how cross-sections were developed see WSPRO input file. 


\section{Data and Assumptions Used in WSPRO Model}

Hydraulic analyses of the reach were done by use of the Federal Highway Administration's WSPRO step-backwater computer program (Shearman and others, 1986, and Shearman, 1990). The analyses reported herein reflect conditions existing at the site at the time of the study. Furthermore, in the development of the model it was necessary to assume no accumulation of debris or ice at the site. Results of the hydraulic model are presented in the Bridge Hydraulic Summary, Appendix B, and figure 7.

Channel roughness factors (Manning's " $n$ ") used in the hydraulic model were estimated using field inspections at each cross section following the general guidelines described by Arcement and Schneider (1989). Final adjustments to the values were made during the modelling of the reach. Channel " $n$ " values for the reach ranged from 0.035 to 0.047 , and overbank " $n$ " values ranged from 0.040 to 0.045 .

The confluence of the Hancock Branch and the White River is approximately 1000 feet downstream of the bridge. The exit section of the bridge was used as a template section and the reach between the confluence and the bridge was included in the hydraulic analysis. The model was started using water-surface elevations taken from the Flood Insurance Study for the Town

of Hancock, VT (Federal Emergency Management Agency, 1991). It was determined that normal depth was achieved within the reach between the confluence and the bridge.

The surveyed approach section (ATEMP) was moved along the approach channel slope $(0.0094 \mathrm{ft} / \mathrm{ft})$ to establish the modelled approach section (APPRO), one bridge length upstream of the upstream face as recommended by Shearman and others (1986). This approach also provides a consistent method for determining scour variables. 


\section{Bridge Hydraulics Summary}

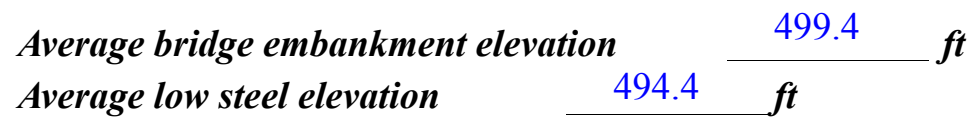

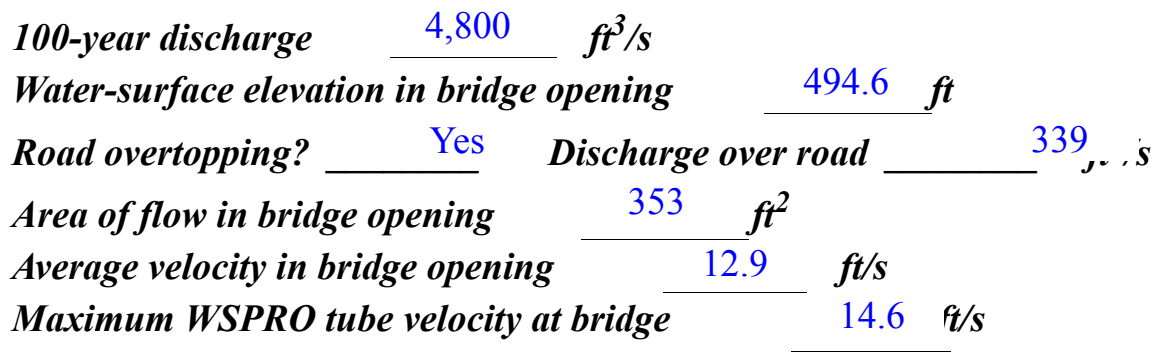

Water-surface elevation at Approach section with bridge 498.8

Water-surface elevation at Approach section without bridge $\quad \overline{495.4}$

Amount of backwater caused by bridge $\quad 3.4$ it

500-year discharge $\quad 7,000 \quad \mathrm{ft}^{3} / \mathrm{s}$

Water-surface elevation in bridge opening

$494.6 \mathrm{ft}$

Road overtopping? ___ Yes Discharge over road _ $2,330, \mathrm{it}^{3 / s}$

Area of flow in bridge opening $\quad 353 \quad \mathrm{ft}^{2}$

Average velocity in bridge opening $13.3 \mathrm{ft} / \mathrm{s}$

Maximum WSPRO tube velocity at bridge 15.4 's

Water-surface elevation at Approach section with bridge $\quad 500.0$

Water-surface elevation at Approach section without bridge $\quad 496.2$

Amount of backwater caused by bridge 3.8 .

Incipient overtopping discharge $\quad 4,390 \quad \boldsymbol{f t}^{3} / \mathrm{s}$

Water-surface elevation in bridge opening 494.6 t

Area of flow in bridge opening $\quad 353 \quad \mathrm{ft}^{2}$

Average velocity in bridge opening $\quad 12.2 \quad \mathrm{ft} / \mathrm{s}$

Maximum WSPRO tube velocity at bridge $\quad 14.4 \quad \mathrm{ft} / \mathrm{s}$

Water-surface elevation at Approach section with bridge

Water-surface elevation at Approach section without bridge

498.2

Amount of backwater caused by bridge $\quad 3.0$.t 


\section{Scour Analysis Summary}

\section{Special Conditions or Assumptions Made in Scour Analysis}

Scour depths were computed using the general guidelines described in Hydraulic Engineering Circular 18 (Richardson and others, 1995). Scour depths were calculated assuming an infinite depth of erosive material and a homogeneous particle-size distribution. The results of the scour analysis are presented in tables 1 and 2 and a graph of the scour depths is presented in figure 8 .

All discharges resulted in orifice flow. Contraction scour at bridges with orifice flow is best estimated by use of the Chang pressure-flow scour equation (oral communication, J. Sterling Jones, October 4, 1996). Thus, contraction scour was computed by the Chang equation (Richardson and others, 1995, p. 145-146). The results of Laursen's clear-water contraction scour equation (Richardson and others, 1995, p. 32, equation 20) were also computed and can be found in appendix F.

Abutment scour for the left abutment was computed by use of the Froehlich equation (Richardson and others, 1995, p. 48, equation 28). Variables for the Froehlich equation include the Froude number of the flow approaching the embankments, the length of the embankment blocking flow, and the depth of flow approaching the embankment less any roadway overtopping.

Scour at the right abutment for all discharges was computed by use of the HIRE equation (Richardson and others, 1995, p. 49, equation 29) because the HIRE equation is recommended when the length to depth ratio of the embankment blocking flow exceeds 25 . The variables used by the HIRE abutment-scour equation are defined the same as those defined for the Froehlich abutment-scour equation. 


\section{Scour Results}

100-yr discharge 500-yrdischarge

Incipient

overtopping

Contraction scour:

(Scour depths in feet)

Main channel

Live-bed scour

Clear-water scour

Depth to armoring

Left overbank

Right overbank

Local scour:

Abutment scour

Left abutment

11.1

10.0

10.3

$8.6-$

$9.2-$

8.2-

Right abutment

Pier scour

Pier 1

Pier 2

Pier 3

Abutments:

Left abutment

Right abutment

Piers:

Pier 1

Pier 2

\section{Riprap Sizing}

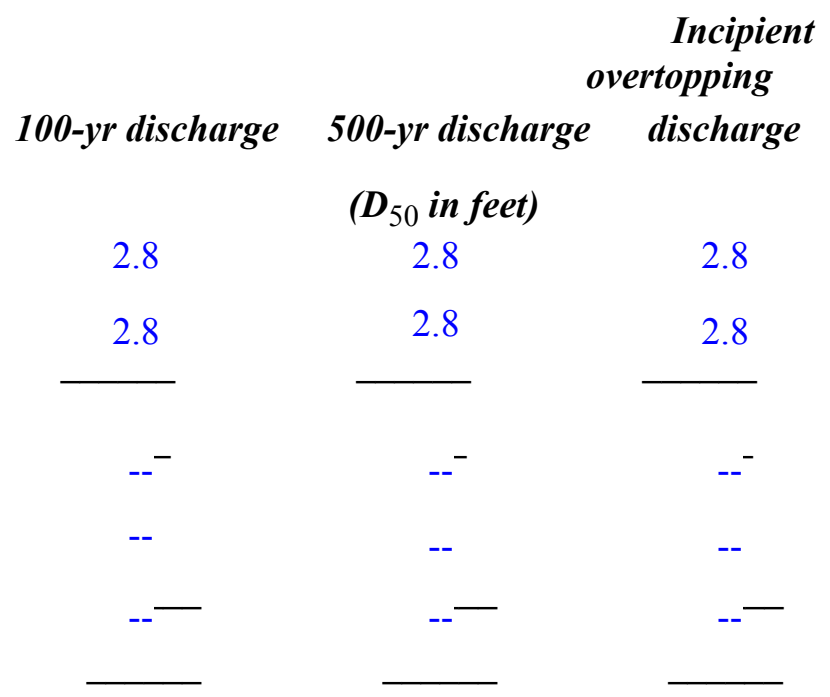




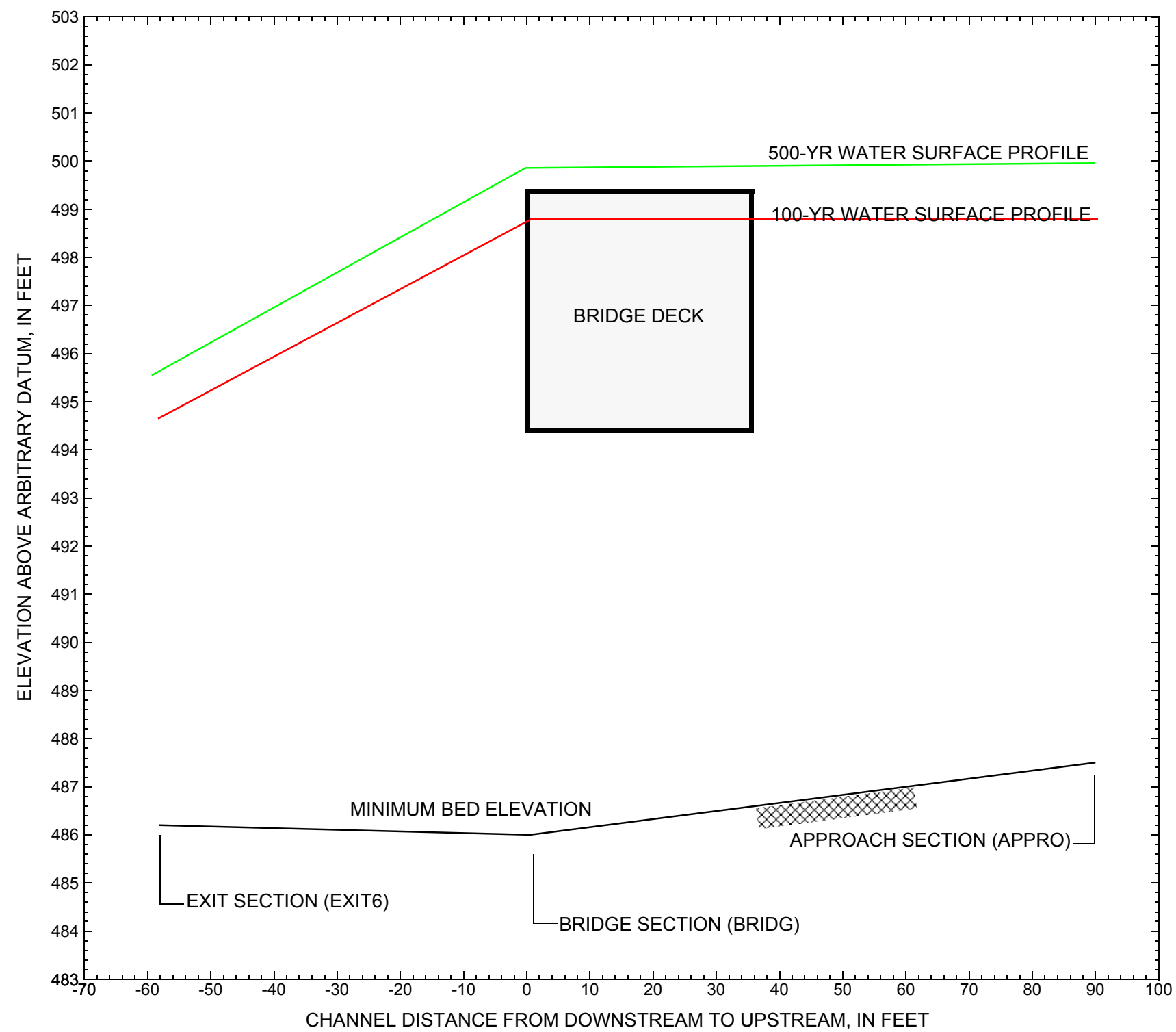

Figure 7. Water-surface profiles for the 100- and 500-yr discharges at structure HANCVT01000145 on State Route 100, crossing the Hancock Branch of the White River, Hancock, Vermont. 


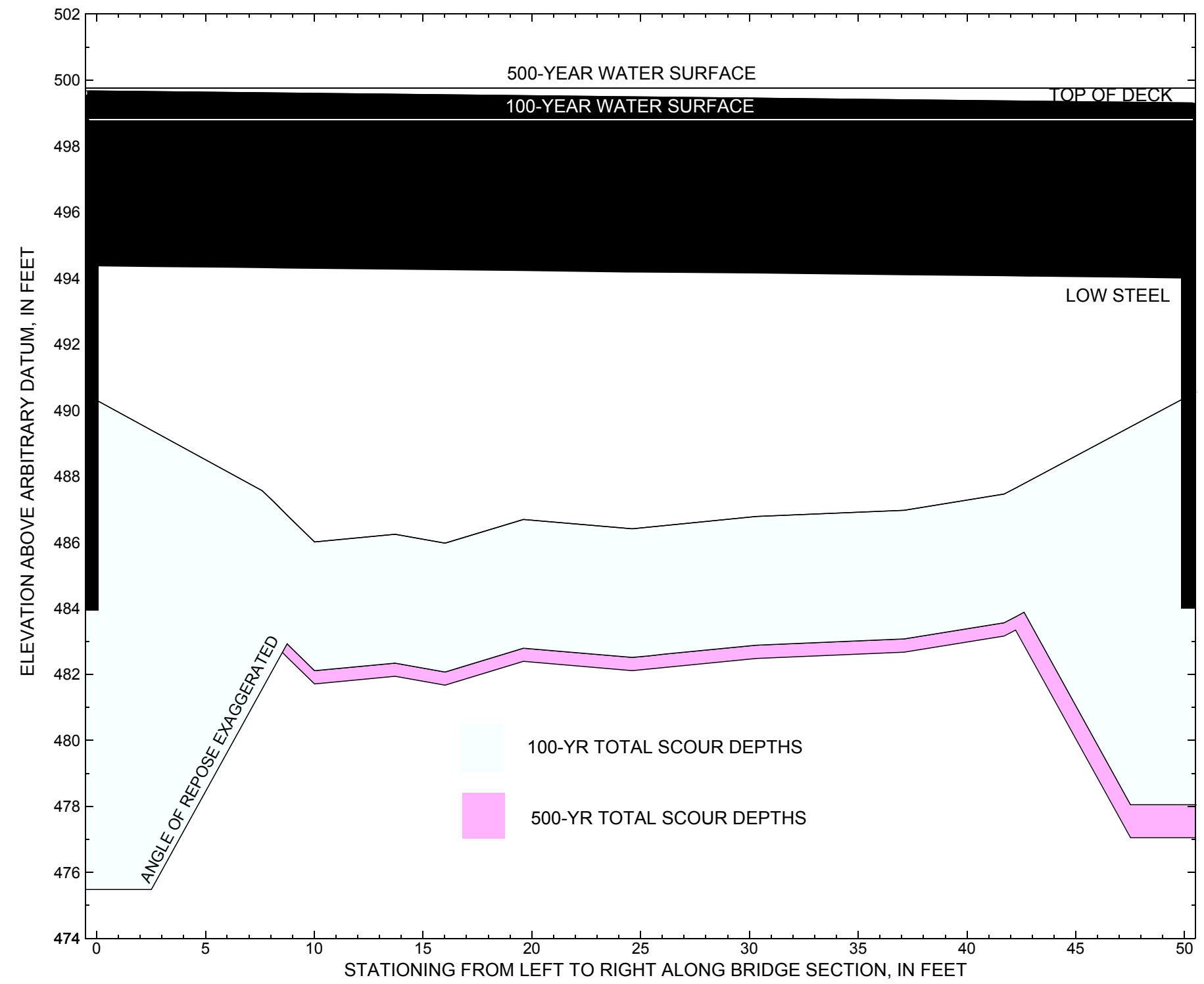

Figure 8. Scour elevations for the 100-yr and 500-yr discharges at structure HANCVT01000145 on State Route 100, crossing the Hancock Branch of the White River, Hancock, Vermont. 
Table 1. Remaining footing/pile depth at abutments for the 100-year discharge at structure HANCVT01000145 on State Route 100 , crossing the Hancock Branch of the White River, Hancock, Vermont.

[VTAOT, Vermont Agency of Transportation; --,no data]

\begin{tabular}{|c|c|c|c|c|c|c|c|c|c|c|c|}
\hline Description & Station $^{1}$ & $\begin{array}{l}\text { VTAOT } \\
\text { minimum } \\
\text { bridge seat } \\
\text { elevation } \\
\text { (feet) }\end{array}$ & $\begin{array}{l}\text { Surveyed } \\
\text { minimum } \\
\text { low-chord } \\
\text { elevation } \\
\text { (feet) }\end{array}$ & $\begin{array}{l}\text { Bottom of } \\
\text { footing } \\
\text { elevation } \\
\text { (feet) }\end{array}$ & $\begin{array}{l}\text { Channel } \\
\text { elevation at } \\
\text { abutment/ } \\
\text { pier }^{2} \\
\text { (feet) }\end{array}$ & $\begin{array}{l}\text { Contraction } \\
\text { scour depth } \\
\text { (feet) }\end{array}$ & $\begin{array}{l}\text { Abutment } \\
\text { scour } \\
\text { depth } \\
\text { (feet) }\end{array}$ & $\begin{array}{l}\text { Pier } \\
\text { scour } \\
\text { depth } \\
\text { (feet) }\end{array}$ & $\begin{array}{l}\text { Depth of } \\
\text { total scour } \\
\text { (feet) }\end{array}$ & $\begin{array}{c}\text { Elevation of } \\
\text { scour }^{2} \\
\text { (feet) }\end{array}$ & $\begin{array}{c}\text { Remaining } \\
\text { footing/pile } \\
\text { depth } \\
\text { (feet) }\end{array}$ \\
\hline \multicolumn{12}{|c|}{100 -yr. discharge is 4,800 cubic-feet per second } \\
\hline Left abutment & 0.0 & 908.8 & 494.6 & 484 & 490.5 & 3.9 & 11.1 & -- & 15.0 & 475.5 & -8 \\
\hline Right abutment & 50.2 & 908.6 & 494.3 & 484 & 490.5 & 3.9 & 8.6 & -- & 12.5 & 478.0 & -6 \\
\hline
\end{tabular}

1.Measured along the face of the most constricting side of the bridge.

2.Arbitrary datum for this study.

Table 2. Remaining footing/pile depth at abutments for the 500-year discharge at structure HANCVT01000145 on State Route 100, crossing the Hancock Branch of the White River, Hancock, Vermont.

[VTAOT, Vermont Agency of Transportation; --, no data]

\begin{tabular}{|c|c|c|c|c|c|c|c|c|c|c|c|}
\hline Description & Station ${ }^{1}$ & $\begin{array}{l}\text { VTAOT } \\
\text { minimum } \\
\text { bridge seat } \\
\text { elevation } \\
\text { (feet) }\end{array}$ & $\begin{array}{c}\text { Surveyed } \\
\text { minimum } \\
\text { low-chord } \\
\text { elevation } \\
\text { (feet) }\end{array}$ & $\begin{array}{l}\text { Bottom of } \\
\text { footing } \\
\text { elevation } \\
\text { (feet) }\end{array}$ & $\begin{array}{c}\text { Channel } \\
\text { elevation at } \\
\text { abutment/ } \\
\text { pier }^{2} \\
\text { (feet) }\end{array}$ & $\begin{array}{l}\text { Contraction } \\
\text { scour depth } \\
\text { (feet) }\end{array}$ & $\begin{array}{l}\text { Abutment } \\
\text { scour } \\
\text { depth } \\
\text { (feet) }\end{array}$ & $\begin{array}{l}\text { Pier } \\
\text { scour } \\
\text { depth } \\
\text { (feet) }\end{array}$ & $\begin{array}{l}\text { Depth of } \\
\text { total scour } \\
\text { (feet) }\end{array}$ & $\begin{array}{c}\text { Elevation of } \\
\text { scour }^{2} \\
\text { (feet) }\end{array}$ & $\begin{array}{c}\text { Remaining } \\
\text { footing/pile } \\
\text { depth } \\
\text { (feet) }\end{array}$ \\
\hline \multicolumn{12}{|c|}{500 -yr. discharge is 7,000 cubic-feet per second } \\
\hline Left abutment & 0.0 & 908.8 & 494.6 & 484 & 490.5 & 4.3 & 10.0 & -- & 14.3 & 476.2 & -8 \\
\hline Right abutment & 50.2 & 908.6 & 494.3 & 484 & 490.5 & 4.3 & 9.2 & -- & 13.5 & 477.0 & -7 \\
\hline
\end{tabular}

1.Measured along the face of the most constricting side of the bridge.

2.Arbitrary datum for this study. 


\section{SELECTED REFERENCES}

Arcement, G.J., Jr., and Schneider, V.R., 1989, Guide for selecting Manning's roughness coefficients for natural channels and flood plains: U.S. Geological Survey Water-Supply Paper 2339, 38 p.

Barnes, H.H., Jr., 1967, Roughness characteristics of natural channels: U.S. Geological Survey Water-Supply Paper 1849,213 p.

Benson, M. A., 1962, Factors Influencing the Occurrence of Floods in a Humid Region of Diverse Terrain: U.S. Geological Survey WaterSupply Paper 1580-B, 64 p.

Brown, S.A. and Clyde, E.S., 1989, Design of riprap revetment: Federal Highway Administration Hydraulic Engineering Circular No. 11, Publication FHWA-IP-89-016, 156 p.

Federal Emergency Management Agency, 1991, Flood Insurance Study, Town of Hancock, Addison County, Vermont: Washington, D.C., August 19, 1991.

Froehlich, D.C., 1989, Local scour at bridge abutments in Ports, M.A., ed., Hydraulic Engineering--Proceedings of the 1989 National Conference on Hydraulic Engineering: New York, American Society of Civil Engineers, p. 13-18.

Hayes, D.C.,1993, Site selection and collection of bridge-scour data in Delaware, Maryland, and Virginia: U.S. Geological Survey WaterResources Investigation Report 93-4017, 23 p.

Johnson, C.G. and Tasker, G.D.,1974, Progress report on flood magnitude and frequency of Vermont streams: U.S. Geological Survey OpenFile Report 74-130, 37 p.

Interagency Advisory Committee on Water Data, 1982, Guidelines for determining flood flow frequency: U.S. Geological Survey, Bulletin 17B of the Hydrology Subcommittee, 190 p.

Lagasse, P.F., Schall, J.D., Johnson, F., Richardson, E.V., Chang, F., 1995, Stream Stability at Highway Structures: Federal Highway Administration Hydraulic Engineering Circular No. 20, Publication FHWA-IP-90-014, 144 p.

Laursen, E.M., 1960, Scour at bridge crossings: Journal of the Hydraulics Division, American Society of Civil Engineers, v. 86, no. HY2, p. 39-53.

Potter, W. D., 1957a, Peak rates of runoff in the Adirondack, White Mountains, and Maine woods area, Bureau of Public Roads

Potter, W. D., 1957b, Peak rates of runoff in the New England Hill and Lowland area, Bureau of Public Roads

Richardson, E.V. and Davis, S.R., 1995, Evaluating scour at bridges: Federal Highway Administration Hydraulic Engineering Circular No. 18, Publication FHWA-IP-90-017, 204 p.

Richardson, E.V., Simons, D.B., and Julien, P.Y., 1990, Highways in the river environment: Federal Highway Administration Publication FHWA-HI-90-016.

Ritter, D.F., 1984, Process Geomorphology: W.C. Brown Co., Debuque, Iowa, 603 p.

Shearman, J.O., 1990, User's manual for WSPRO--a computer model for water surface profile computations: Federal Highway Administration Publication FHWA-IP-89-027, 187 p.

Shearman, J.O., Kirby, W.H., Schneider, V.R., and Flippo, H.N., 1986, Bridge waterways analysis model; research report: Federal Highway Administration Publication FHWA-RD-86-108, 112 p.

Talbot, A.N., 1887, The determination of water-way for bridges and culverts.

U.S. Department of Transportation, 1993, Stream stability and scour at highway bridges, Participant Workbook: Federal Highway Administration Publication FHWA HI-91-011.

U.S. Geological Survey, 1970, Hancock, Vermont 7.5 Minute Series quadrangle map: U.S. Geological Survey Topographic Maps, Scale $1: 24,000$. 


\section{APPENDIX A: \\ WSPRO INPUT FILE}


WSPRO INPUT FILE

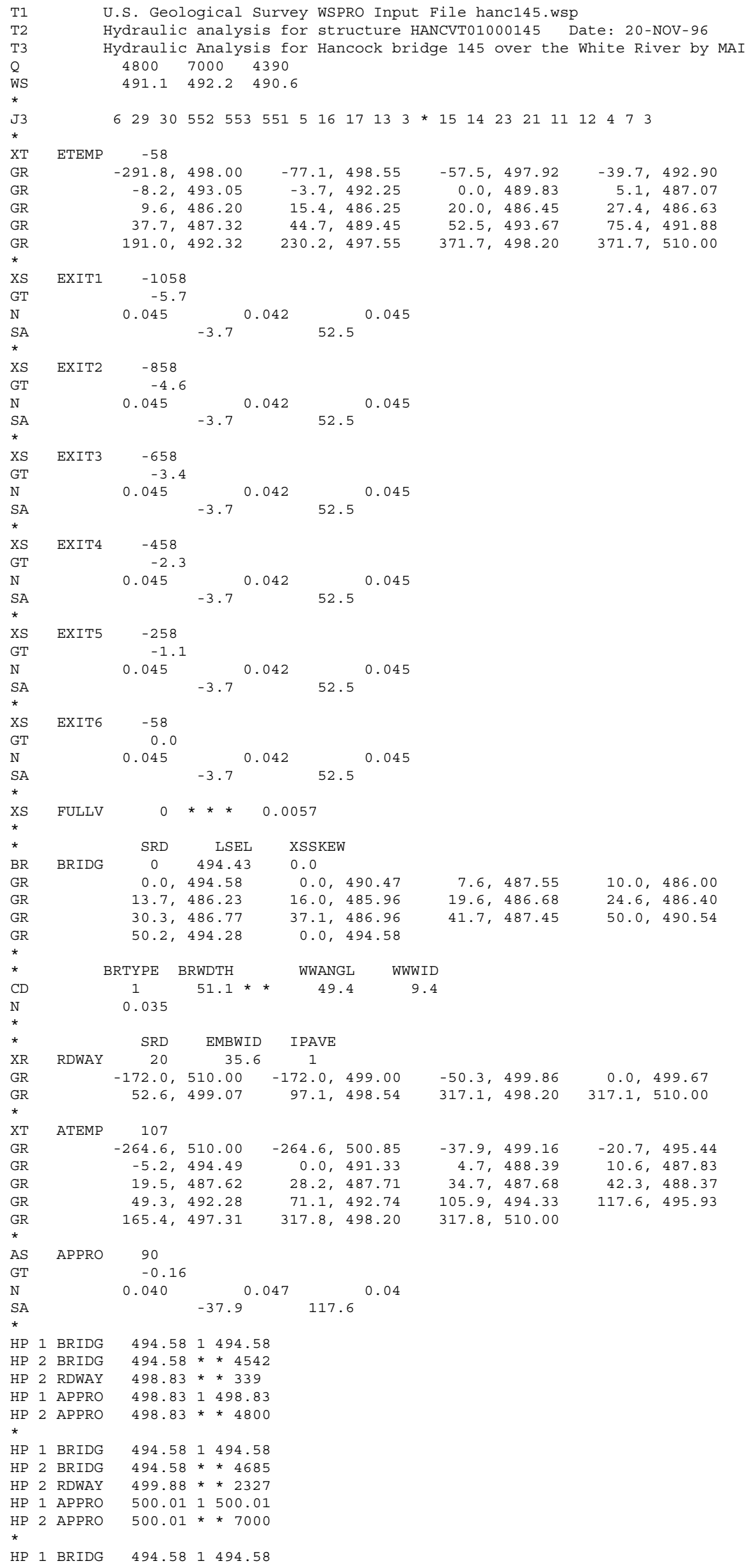




\section{APPENDIX B: \\ WSPRO OUTPUT FILE}




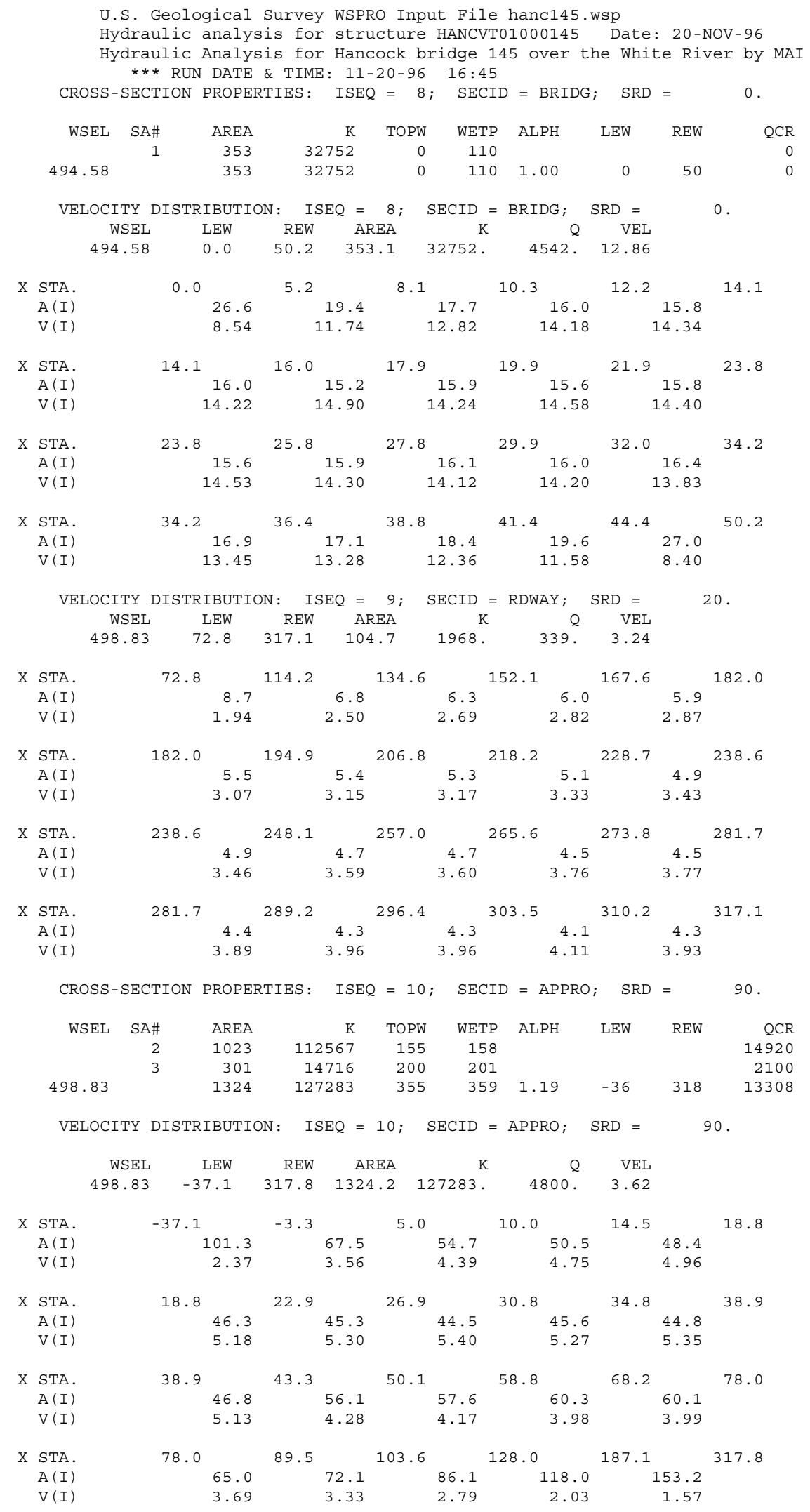


WSPRO OUTPUT FILE (continued)

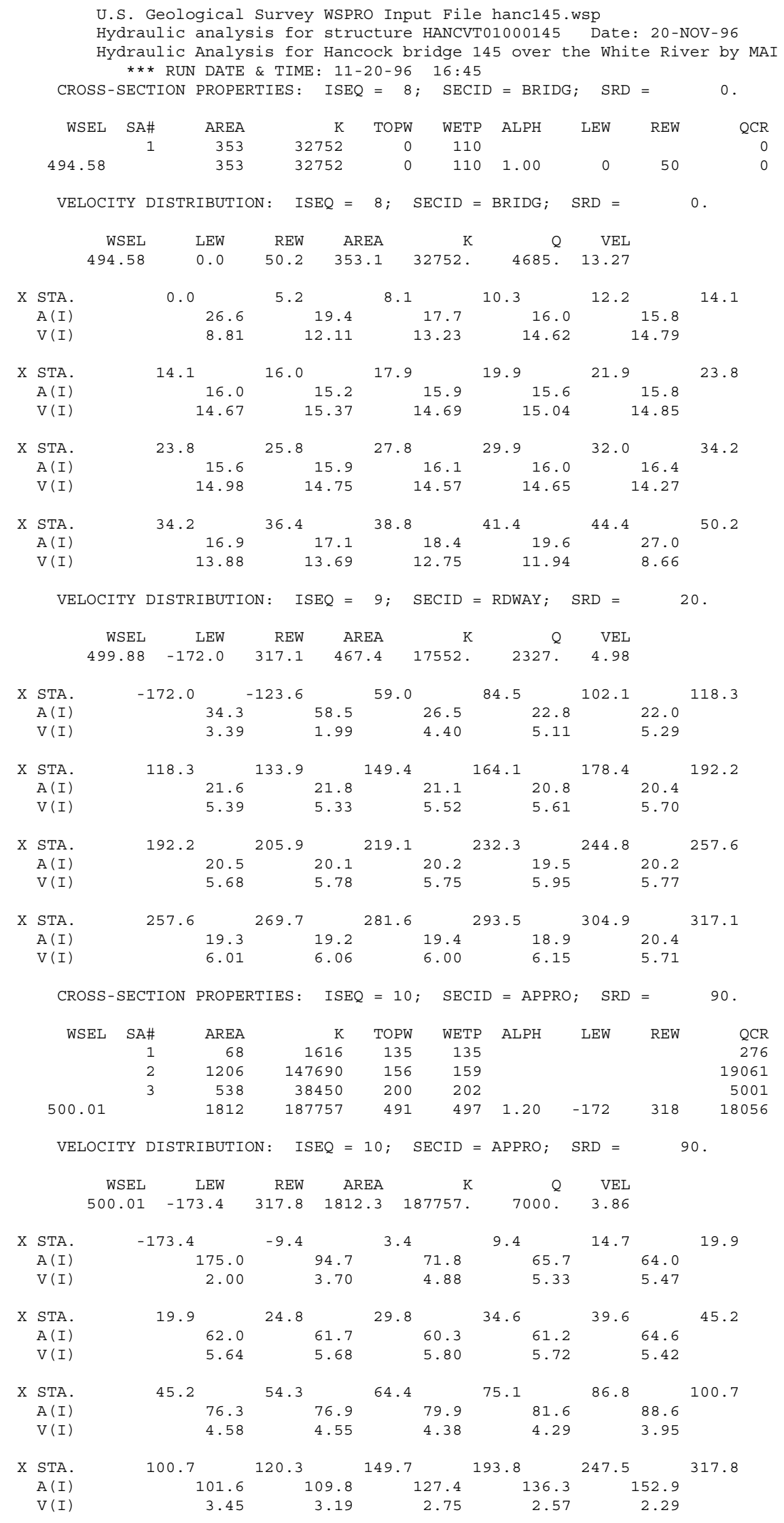


WSPRO OUTPUT FILE (continued)

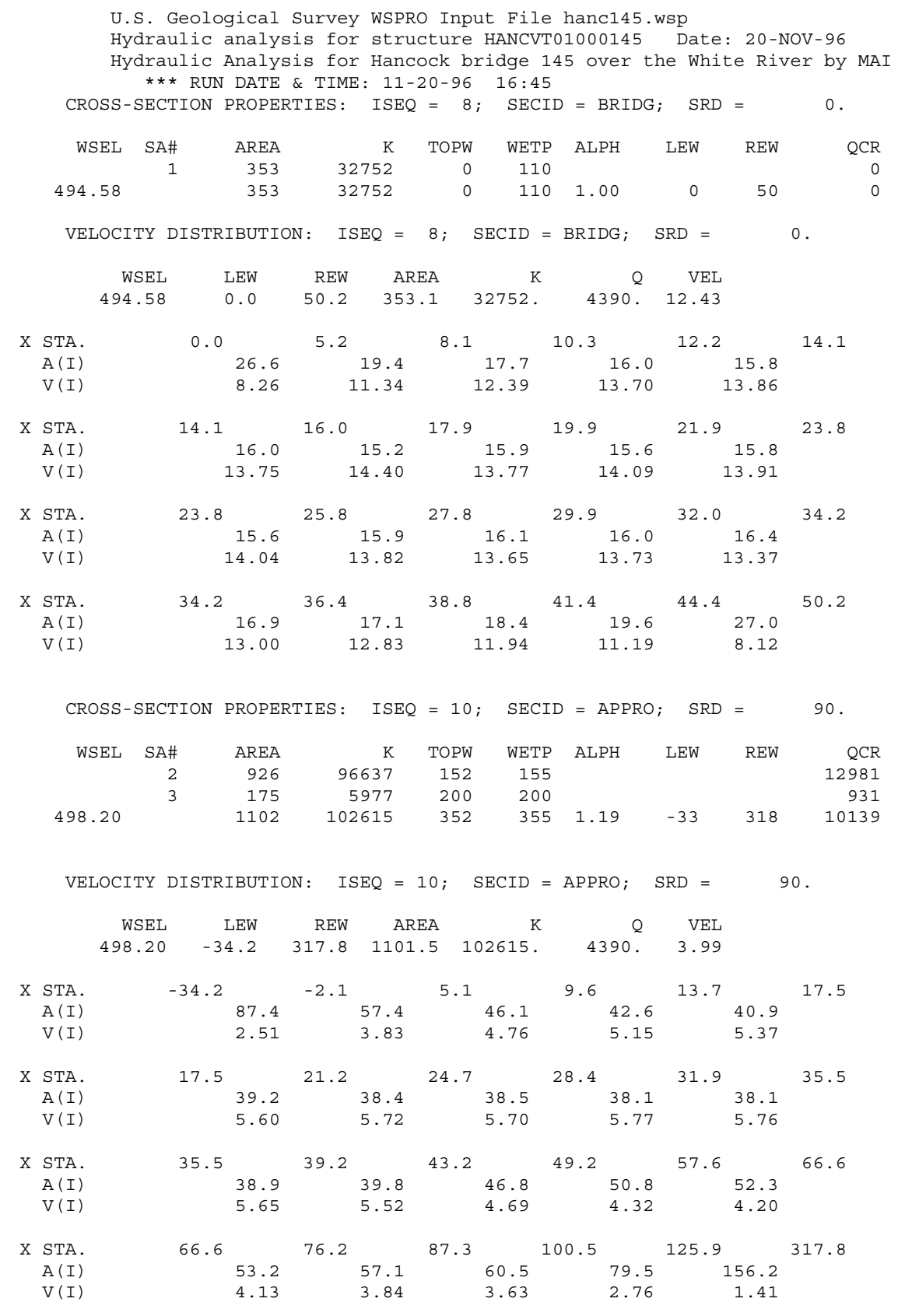


WSPRO OUTPUT FILE (continued)

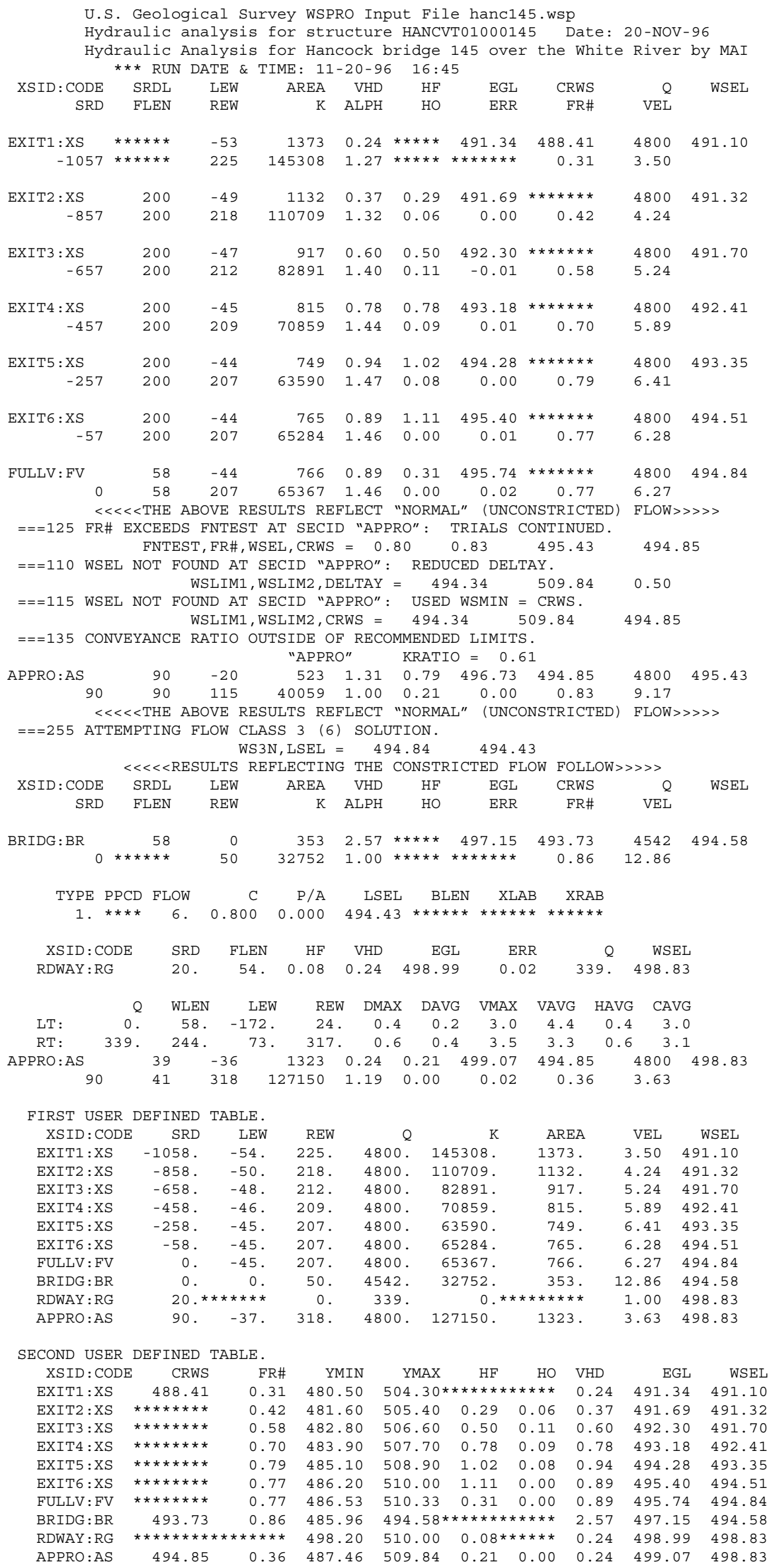


WSPRO OUTPUT FILE (continued)

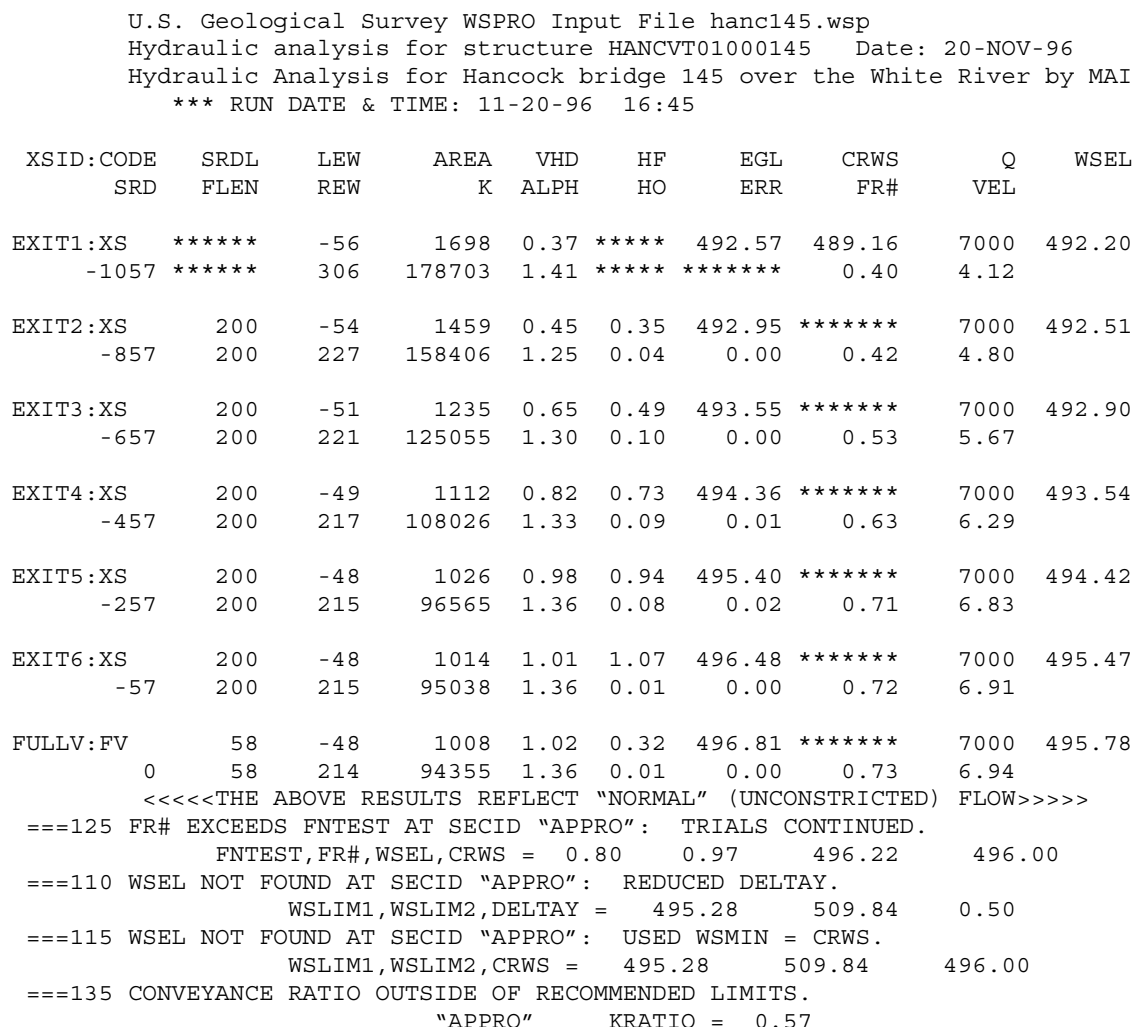

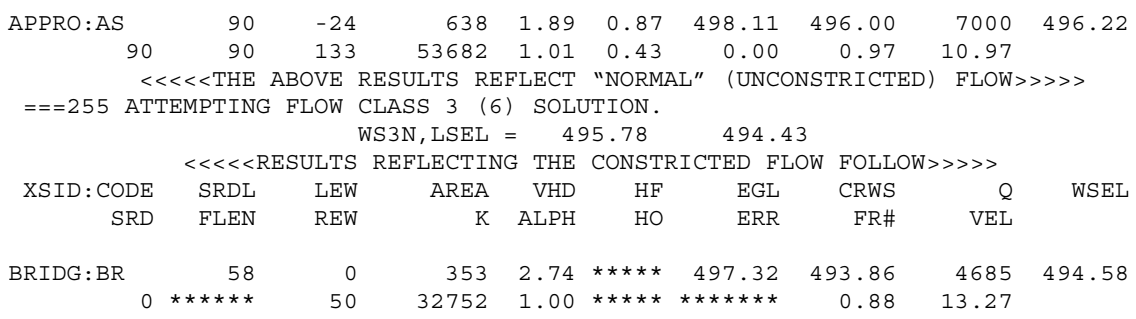

TYPE PPCD FLOW C P/A LSEL BLEN XLAB XRAB

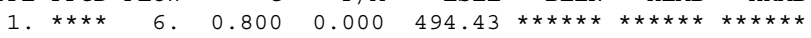

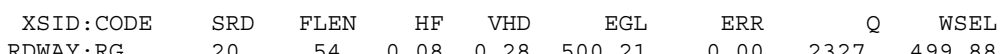

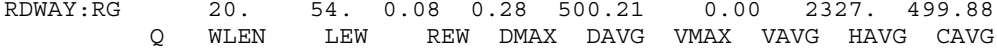

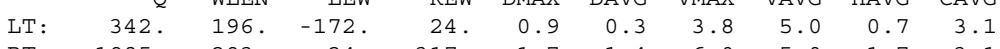

$\begin{array}{lllllllll}\mathrm{RT} & \text { 1985. 293. } 24 . & 317 . & 1.7 & 1.4 & 6.0 & 5.0 & 1.7 & 3.1\end{array}$

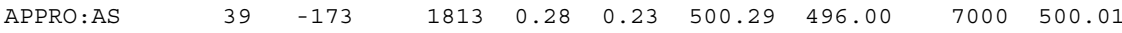
$\begin{array}{lllrrrrrr}90 & 42 & 318 & 187875 & 1.20 & 0.00 & 0.00 & 0.39 & 3.86\end{array}$

FIRST USER DEFINED TABLE.

\begin{tabular}{|c|c|c|c|c|c|c|c|c|}
\hline XSID : CODE & SRD & LEW & REW & c & $\mathrm{K}$ & AREA & VEL & WSEI \\
\hline EXIT1:XS & -1058 & -57 & 306. & 7000. & 178703. & 1698. & 4.12 & 492.20 \\
\hline EXIT2:XS & -858 & -55 & 227. & 7000. & 158406. & 1459. & 4.80 & 492.51 \\
\hline EXIT3:XS & -658 & -52. & 221. & 7000. & 125055 . & 1235. & 5.67 & 492.90 \\
\hline EIT4:XS & -458. & -50 & 217. & 7000. & 108026 . & 1112. & 6.29 & 493.54 \\
\hline EXIT5:XS & -258 & -49 . & 215. & 7000. & 96565 . & 1026. & 6.83 & 494.42 \\
\hline EXIT6:XS & -58 & -49 & 215. & 7000. & 95038. & 1014. & 6.91 & 495.47 \\
\hline FULLV : FV & 0 . & -49 & 214. & 7000. & 94355 . & 1008. & 6.94 & 495.78 \\
\hline BRIDG : BR & 0 . & 0 & 50. & 4685. & 32752 . & 353. & 13.27 & 494.58 \\
\hline RDWAY : RG & $20 . *$ & $\star \star \star \star * *$ & 342 . & 2327. & 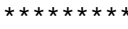 & $\star \star \star \star \star \star * *$ & 1.00 & 499.88 \\
\hline APPRO:AS & 90. & -174. & 318. & 7000. & 187875 . & 1813. & 3.86 & 500.01 \\
\hline
\end{tabular}

SECOND USER DEFINED TABLE.

$\begin{array}{lrrrrrrrrr}\text { XSID:CODE } & \text { CRWS } & \text { FR\# } & \text { YMIN } & \text { YMAX } & \text { HF } & \text { HO } & \text { VHD } & \text { EGL } & \text { WSEL } \\ \text { EXIT1:XS } & 489.16 & 0.40 & 480.50 & 504.30 * * * * * * * * * * & 0.37 & 492.57 & 492.20 \\ \text { EXIT2:XS } & * * * * * * * * & 0.42 & 481.60 & 505.40 & 0.35 & 0.04 & 0.45 & 492.95 & 492.51 \\ \text { EXIT3:XS } & * * * * * * * * & 0.53 & 482.80 & 506.60 & 0.49 & 0.10 & 0.65 & 493.55 & 492.90 \\ \text { EXIT4:XS } & * * * * * * * * & 0.63 & 483.90 & 507.70 & 0.73 & 0.09 & 0.82 & 494.36 & 493.54 \\ \text { EXIT5:XS } & * * * * * * * * & 0.71 & 485.10 & 508.90 & 0.94 & 0.08 & 0.98 & 495.40 & 494.42 \\ \text { EXIT6:XS } & * * * * * * * * & 0.72 & 486.20 & 510.00 & 1.07 & 0.01 & 1.01 & 496.48 & 495.47 \\ \text { FULLV: FV } & * * * * * * * * & 0.73 & 486.53 & 510.33 & 0.32 & 0.01 & 1.02 & 496.81 & 495.78 \\ \text { BRIDG:BR } & 493.86 & 0.88 & 485.96 & 494.58 * * * * * * * * * * * & 2.74 & 497.32 & 494.58 \\ \text { RDWAY: RG } & * * * * * * * * * * * * * * & 498.20 & 510.00 & 0.08 * * * * * * & 0.28 & 500.21 & 499.88 \\ \text { APPRO:AS } & 496.00 & 0.39 & 487.46 & 509.84 & 0.23 & 0.00 & 0.28 & 500.29 & 500.01\end{array}$


WSPRO OUTPUT FILE (continued)

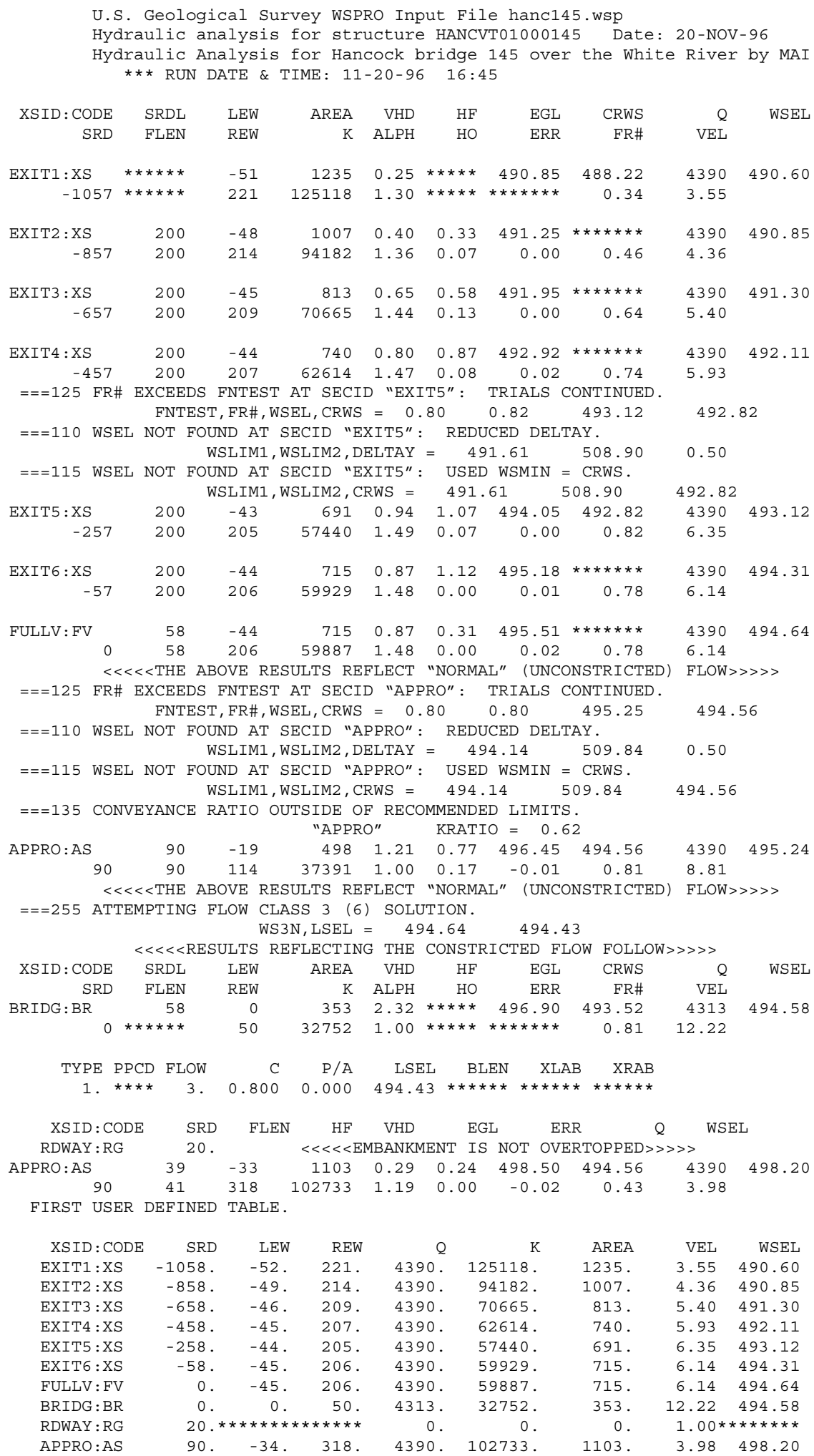

SECOND USER DEFINED TABLE.

\begin{tabular}{|c|c|c|c|c|c|c|c|c|c|}
\hline XSID : CODE & CRWS & FR\# & YMIN & YMAX & $\mathrm{HF}$ & $\mathrm{HO}$ & VHD & EGL & WSEL \\
\hline EXIT1:XS & 488.22 & 0.34 & 480.50 & $504.30 *$ & $\star * \star \star \star * \star *$ & $\star \star \star \star * *$ & 0.25 & 490.85 & 490.60 \\
\hline EXIT2:XS & 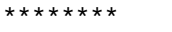 & 0.46 & 481.60 & 505.40 & 0.33 & 0.07 & 0.40 & 491.25 & 490.85 \\
\hline EXIT3:XS & $\star * * * * * * *$ & 0.64 & 482.80 & 506.60 & 0.58 & 0.13 & 0.65 & 491.95 & 491.30 \\
\hline EXIT4 :XS & 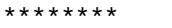 & 0.74 & 483.90 & 507.70 & 0.87 & 0.08 & 0.80 & 492.92 & 492.11 \\
\hline EXIT5:XS & 492.82 & 0.82 & 485.10 & 508.90 & 1.07 & 0.07 & 0.94 & 494.05 & 493.12 \\
\hline EXIT6:XS & $\star \star \star \star * \star * \star * *$ & 0.78 & 486.20 & 510.00 & 1.12 & 0.00 & 0.87 & 495.18 & 494.31 \\
\hline FULLV : FV & 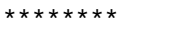 & 0.78 & 486.53 & 510.33 & 0.31 & 0.00 & 0.87 & 495.51 & 494.64 \\
\hline BRIDG : BR & 493.52 & 0.81 & 485.96 & $494.58 *$ & & $\star \star \star \star \star *$ & 2.32 & 496.90 & 494.58 \\
\hline DWAY : RG & 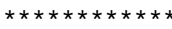 & & 498.20 & 510.00 & & $\star \star \star$ & 0.29 & 498.40 * & 年 \\
\hline APPRO:AS & 494.56 & 0.43 & 487.46 & 509.84 & 0.24 & 0.00 & 0.29 & 498.50 & 498.20 \\
\hline
\end{tabular}




\section{APPENDIX C:}

\section{BED-MATERIAL PARTICAL-SIZE DISTRIBUTION}




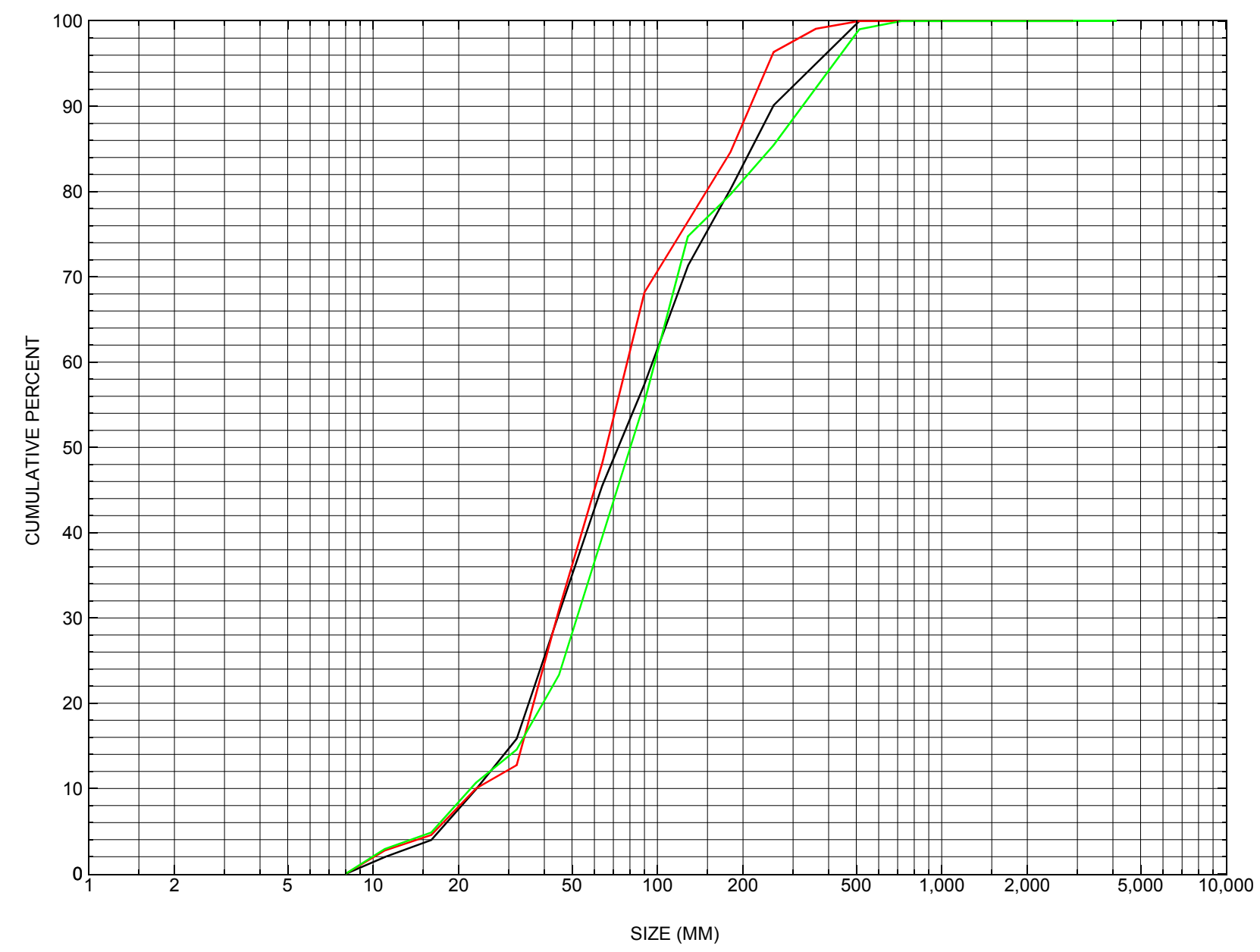

Appendix C. Bed material particle-size distribution for three pebble count transects in the channel approach of structure HANCVT01000145, in Hancock, Vermont. 


\section{APPENDIX D: \\ HISTORICAL DATA FORM}




\section{Structure Number HANCVT01000145}

\section{General Location Descriptive}

Data collected by (First Initial, Full last name) M. IVANOFF

Date $(M M / D D / Y Y) \_\mathbf{0 8} / \underline{\mathbf{2 6}} / \underline{\mathbf{9 4}}$

Highway District Number (I - 2; nn) 04

Town (FIPS place code; I - 4; nnnnn) $\mathbf{3 1 5 2 5}$

Waterway (I - 6) HANCOCK BRANCH

Route Number VT 100

Topographic Map Hancock

Latitude (I - 16; nnnn.n) $\mathbf{4 3 5 5 6}$
County (FIPS county code; I - 3; nnn)

Mile marker (I - 11; nnn.nnn) $\mathbf{0 0 1 1 9 0}$

Road Name (I - 7): -

Vicinity (I - 9) 0.1 MI S JCT. VT.125

Hydrologic Unit Code: $\mathbf{0 1 0 8 0 1 0 5}$

Longitude (i - 17; nnnnn.n) $\mathbf{7 2 5 0 5}$

\section{Select Federal Inventory Codes}

FHWA Structure Number $(I$ - 8) $\quad \mathbf{2 0 0 0 1 3 0 1 4 5 0 1 0 8}$

Maintenance responsibility $(I-21 ; n n) \quad 01$

Year built (I - 27; YYYY) 1979

Average daily traffic, ADT (I - 29; nnnnnn) 001700

Year of ADT (I - 30; YY) $\mathbf{9 2}$

Opening skew to Roadway (I - 34; nn)

Operational status $(I-41 ; X) \underline{\mathbf{A}}$

Structure type (I- 43; nnn) $\mathbf{3 0 2}$

Approach span structure type (I - 44; nnn) $\mathbf{0 0 0}$

Number of spans (I - 45; nnn) $\underline{\mathbf{0 0 1}}$

Number of approach spans (I - 46; nnnn) 0000

Comments:

Structural inspection report of 9/30/93 indicates a single span rolled beam bridge. The stream is on a slight curve to the right abutment. The right abutment is concrete with numerous longitudinal and transverse cracks. Curtain walls are "like new". The wings of the right abutment have some minor scaling. The stem of left abutment has areas of scaling and minor cracking with leakage. Channel is straight through the bridge. Stone fill is in place at both abutments. There is vegetation along the banks. No noted erosion or settlement.
Maximum span length (I - 48; nnnn) $\underline{0053}$

Structure length (I - 49; nnnnnn) $\underline{000055}$

Deck Width (I - 52; nn.n) 356

Channel \& Protection $(I-61 ; n) \underline{7}$

Waterway adequacy $(I-71 ; n) \underline{8}$

Underwater Inspection Frequency $(I-92 B ; X Y Y) \_$N

Year Reconstructed (I - 106) $\mathbf{0 0 0 0}$

Clear span (nnn.n ft) _

Vertical clearance from streambed (nnn.n ft) $\underline{\mathbf{0 0 7 . 0}}$

Waterway of full opening (nnn.n $\left.\mathrm{ft}^{2}\right)$ 


\section{Bridge Hydrologic Data}

Is there hydrologic data available? $\underline{\mathbf{Y}}$ if No, type ctrl-n $h \quad$ VTAOT Drainage area $\left(\mathrm{mi}^{2}\right)^{2}: \underline{\mathbf{2 2 . 4}}$

Terrain character: Hills

Stream character \& type: Fairly straight

Streambed material: Gravelly with type I stone

Discharge Data (cfs): $\quad \mathrm{Q}_{2.33}$ -

$Q_{50} \mathbf{3 2 0 0}$

Record flood date $(M M / D D / Y Y)$ : - $/$ - $/$ -

$\begin{array}{ll}Q_{10} \frac{\mathbf{2 0 0 0}}{\mathbf{3 8 0 0}} & Q_{25} \stackrel{\mathbf{2 6 0 0}}{\mathrm{Q}_{100}} \mathrm{Q}_{500}-\end{array}$

Water surface elevation $(f t):-$

Estimated Discharge (cfs): _- Velocity at Q $\underline{\mathbf{5 0}}(\mathrm{ft} / \mathrm{s}): \underline{\mathbf{1 1 . 4}}$

Ice conditions (Heavy, Moderate, Light) : -

Debris (Heavy, Moderate, Light): -

The stage increases to maximum highwater elevation (Rapidly, Not rapidly): Rapidly

The stream response is (Flashy, Not flashy): Flashy

Describe any significant site conditions upstream or downstream that may influence the stream's

stage: Upstream there is a pond. It is a diversion off from the main channel no significant effect on the drainage area, the outlet was dry.

Watershed storage area (in percent):

The watershed storage area is: 2 (1-mainly at the headwaters; 2- uniformly distributed; 3-immediatly upstream oi the site)

Water Surface Elevation Estimates for Existing Structure:

\begin{tabular}{|l|l|l|l|l|l|}
\hline Peak discharge frequency & $Q_{2.33}$ & $Q_{10}$ & $Q_{25}$ & $Q_{50}$ & $Q_{100}$ \\
Water surface elevation (ft)) & - & $\mathbf{9 0 8 . 4}$ & $\mathbf{9 0 9 . 4}$ & $\mathbf{9 1 0 . 3}$ & $\mathbf{9 1 1 . 2}$ \\
Velocity $(\mathrm{ft} / \mathrm{sec})$ & - & - & - & $\mathbf{1 1 . 4}$ & - \\
\hline
\end{tabular}

Long term stream bed changes: -

Is the roadway overtopped below the $\mathrm{Q}_{100}$ ? (Yes, No, Unknown): $\mathbf{U} \quad$ Frequency: -

Relief Elevation (ft):

Discharge over roadway at $\mathrm{Q}_{100}\left(f^{3} / \mathrm{sec}\right)$ : -

Are there other structures nearby? (Yes, No, Unknown): $\mathbf{U}$

Upstream distance (miles): Town: If No or Unknown, type ctrl-n os

Highway No. : Structure No. : Year Built:

Clear span (ft): Clear Height (ft): Full Waterway $\left(f^{2}\right)$ : 
Downstream distance (miles): Town: Year Built:

Highway No. : Structure No. : Structure Type:

Clear span (ft): Clear Height $(f t)$ : Full Waterway $\left(f t^{2}\right)$ :

Comments:

\section{USGS Watershed Data}

Watershed Hydrographic Data

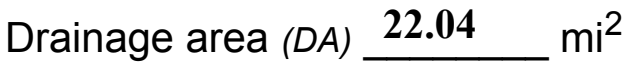
Lake and pond area

0.01 $\mathrm{mi}^{2}$

Watershed storage (ST) 0.1 Bridge site elevation 900 $\mathrm{ft}$ $\%$

Main channel length 7.85 $\mathrm{mi}$ $10 \%$ channel length elevation 950 $\mathrm{ft} \quad 85 \%$ channel length elevation $\mathrm{ft}$

Main channel slope $(S)$

(S) 212.32 $\mathrm{ft} / \mathrm{mi}$

Watershed Precipitation Data

Average site precipitation in

Average headwater precipitation in

Maximum 2yr-24hr precipitation event $(124,2)$ in

Average seasonal snowfall (Sn) $\mathrm{ft}$ 


\section{Bridge Plan Data}

Are plans available? $\underline{Y}$ If no, type ctrl-n pl Date issued for construction (MM/YYYY): 05 / 1979 Project Number BHF 013-4(5)S Minimum channel bed elevation: 903.0

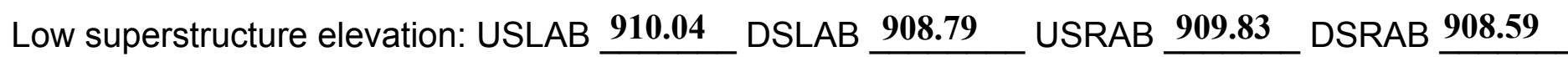
Benchmark location description:

BM \#1 chiseled square at top of the junction of the right abutment and downstream wing elevation 913.72; BM \#2, chiseled square on the concrete deck of "Hubbard's country store", third building on left side of route 125 to Ripton from the intersection with route 100.

Reference Point (MSL, Arbitrary, Other): MSL Datum (NAD27, NAD83, Other): NAD27

Foundation Type: 1 (1-Spreadfooting; 2-Pile; 3- Gravity; 4-Unknown)

If 1: Footing Thickness $\mathbf{2 . 0} \quad$ Footing bottom elevation: $\mathbf{8 9 8 . 0}$

If 2: Pile Type: ___ (1-Wood; 2-Steel or metal; 3-Concrete) Approximate pile driven length: -

If 3: Footing bottom elevation: -

Is boring information available? $\mathbf{N}$ If no, type ctrl-n bi Number of borings taken: _-

Foundation Material Type: $\mathbf{3}$ (1-regolith, 2-bedrock, 3-unknown)

Briefly describe material at foundation bottom elevation or around piles:

NO FOUNDATION MATERIAL INFORMATION

Comments: 


\section{Cross-sectional Data}

Is cross-sectional data available? $\underline{\mathbf{Y}}$ If no, type ctrl-n xs

Source (FEMA, VTAOT, Other)? VTAOT

Comments: Orientation of the cross sections is inconsistent with any cross section data surveyed for this study and is not comparable. Data was not retrieved.

\begin{tabular}{|l|l|l|l|l|l|l|l|l|l|l|l|}
\hline Station & & & & & & & & & & & \\
\hline Feature & & & & & & & & & & & \\
\hline $\begin{array}{l}\text { Low cord } \\
\text { elevation }\end{array}$ & & & & & & & & & & & \\
\hline $\begin{array}{l}\text { Bed } \\
\text { elevation }\end{array}$ & & & & & & & & & & & \\
\hline $\begin{array}{l}\text { Low cord to } \\
\text { bed length }\end{array}$ & & & & & & & & & & & \\
\hline Station & & & & & & & & & & & \\
\hline Feature & & & & & & & & & & & \\
\hline $\begin{array}{l}\text { Low cord } \\
\text { elevation }\end{array}$ & & & & & & & & & & & \\
\hline $\begin{array}{l}\text { Bed } \\
\text { elevation }\end{array}$ & & & & & & & & & & & \\
\hline $\begin{array}{l}\text { Low cord to } \\
\text { bed length }\end{array}$ & & & & & & & & & & & \\
\hline
\end{tabular}

Source (FEMA, VTAOT, Other)?

Comments:

\begin{tabular}{|l|l|l|l|l|l|l|l|l|l|l|l|}
\hline Station & & & & & & & & & & & \\
\hline Feature & & & & & & & & & & & \\
\hline $\begin{array}{l}\text { Low cord } \\
\text { elevation }\end{array}$ & & & & & & & & & & & \\
\hline $\begin{array}{l}\text { Bed } \\
\text { elevation }\end{array}$ & & & & & & & & & & & \\
\hline $\begin{array}{l}\text { Low cord to } \\
\text { bed length }\end{array}$ & & & & & & & & & & & \\
\hline Station & & & & & & & & & & & \\
\hline Feature & & & & & & & & & & & \\
\hline $\begin{array}{l}\text { Low cord } \\
\text { elevation }\end{array}$ & & & & & & & & & & & \\
\hline $\begin{array}{l}\text { Bed } \\
\text { elevation }\end{array}$ & & & & & & & & & & & \\
\hline $\begin{array}{l}\text { Low cord to } \\
\text { bed length }\end{array}$ & & & & & & & & & & & \\
\hline
\end{tabular}




\section{APPENDIX E: \\ LEVEL I DATA FORM}


U. S. Geological Survey

Bridge Field Data Collection and Processing Form

Qa/Qc Check by: Date:

\section{Structure Number}

HANCVT01000145

Computerized by: Date:

Reviewd by: Date:

\section{A. General Location Descriptive}

1. Data collected by (First Initial, Full last name) R. HAMMOND

Date $(M M / D D / Y Y)$

$11 / 16 / 1994$

2. Highway District Number 04

County ADDISON(001)

Waterway (l - 6) HANCOCK BRANCH

Route Number VT 100

3. Descriptive comments:

Bridge is located 0.1 miles South of junction with VT 125.

Bridge plaque states ' $\mathrm{BHF}$ 013-4(5)S' '1980'
Mile marker 001190

Town HANCOCK (31525)

Road Name VT 100

Hydrologic Unit Code: $\mathbf{0 1 0 8 0 1 0 5}$

\section{B. Bridge Deck Observations}
4. Surface cover... LBUS 1
RBUS 6
LBDS 4
RBDS 5
Overall 4

(2b us, ds,lb,rb: 1- Urban; 2- Suburban; 3- Row crops; 4- Pasture; 5- Shrub- and brushland; 6- Forest; 7- Wetland)
5. Ambient water surface... US $\underline{2}$
UB 2
DS $\underline{2}$
(1- pool; 2- riffle)

6. Bridge structure type 1 (1- single span; 2- multiple span; 3- single arch; 4- multiple arch; 5-cylindrical culvert; 6- box culvert; or 7- other)
7. Bridge length $\mathbf{5 5}$
(feet)
Span length $\mathbf{5 3}$
(feet)
Bridge width $\underline{\mathbf{3 5 . 6}}$ (feet)

\section{Road approach to bridge:}
8. LB $\underline{0}$ RB $\underline{0}$
( 0 even, 1- lower, 2- higher)
9. LB 1
RB 1
(1- Paved, 2- Not paved)

10. Embankment slope (run / rise in feet / foot)

$$
\text { US left }
$$$$
\text { 2.7:1 }
$$

US right

2.2:1

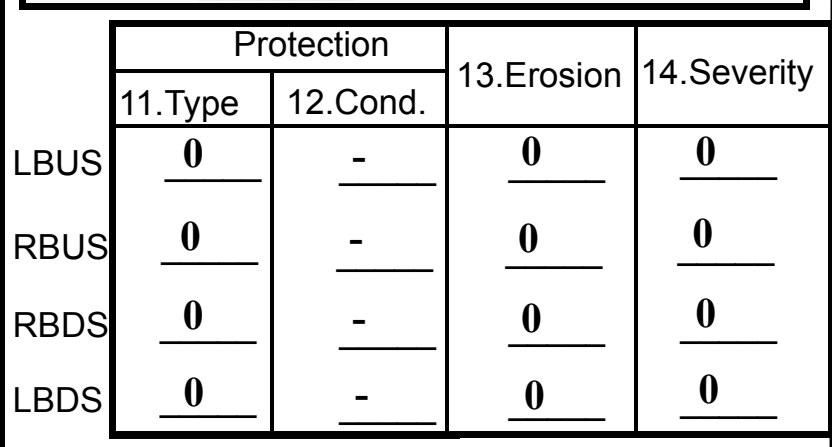

Bank protection types: 0- none; 1- < 12 inches;

$$
\text { 2- < } 36 \text { inches; } 3 \text { - < } 48 \text { inches; }
$$

4- < 60 inches; 5- wall / artificial levee

Bank protection conditions: 1- good; 2- slumped;

3- eroded; 4- failed

Erosion: 0 - none; 1- channel erosion; 2

road wash; 3- both; 4- other

Erosion Severity: 0 - none; 1- slight; 2- moderate; 3- severe

\section{Channel approach to bridge (BF):}

15. Angle of approach: $\mathbf{0}$

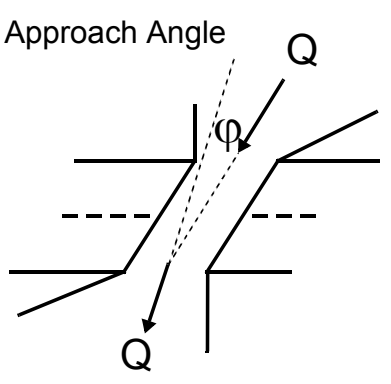

17. Channel impact zone 1 :

Where? LB (LB, RB)

Range? 90 feet $\underline{\mathbf{S}}$

Channel impact zone 2:

Where? (LB, RB)

Range? feet (US, UB, DS) to feet

16. Bridge skew: $\mathbf{0}$ Bridge Skew Angle

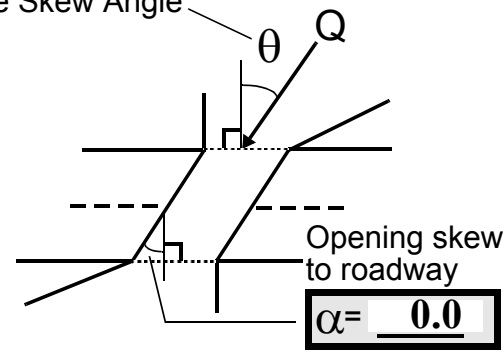

\section{Exist? $\mathbf{Y}(Y$ or $N)$}

Severity 1

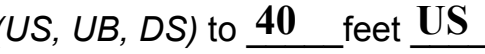

Exist? $\underline{\mathbf{N}}(\mathrm{Y}$ or $N)$

Severity

Impact Severity: 0- none to very slight; 1- Slight; 2- Moderate; 3- Severe 
18. Bridge Type: 1a

1a- Vertical abutments with wingwalls

1 b- Vertical abutments without wingwalls

2- Vertical abutments and wingwalls, sloping embankment

Wingwalls perpendicular to abut. face

3- Spill through abutments

4- Sloping embankment, vertical wingwalls and abutments

1a with wingwalls

Wingwall angle less than $90^{\circ}$.

19. Bridge Deck Comments (surface cover variations, measured bridge and span lengths, bridge type variations, approach overflow width, etc.)

7. Values are from VTAOT database (VTAOT, August 26, 1994). Measured bridge length: 54, span: 52, and width: 35 feet.

Road overflow width is $\mathbf{3 6}$ feet.

18. Wingwall tops slope down, but end is above the low chord elevation.

\section{Upstream Channel Assessment}

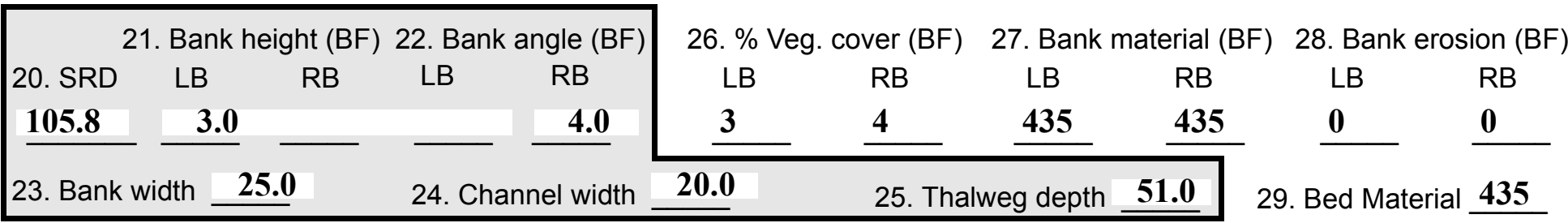

30 .Bank protection type: LB $\underline{0}$

RB 0

31. Bank protection condition: LB -

$\mathrm{RB}$ -

SRD - Section ref. dist. to US face \% Vegetation (Veg) cover: 1- 0 to 25\%; 2- 26 to $50 \%$; 3- 51 to $75 \%$; $4-76$ to $100 \%$

Bed and bank Material: 0- organics; 1- silt / clay, <1/16mm; 2- sand, 1/16 - 2mm; 3- gravel, 2 - 64mm;

4- cobble, 64 - 256mm; 5- boulder, > 256mm; 6- bedrock; 7-manmade

Bank Erosion: 0- not evident; 1- light fluvial; 2- moderate fluvial; 3- heavy fluvial / mass wasting

Bank protection types: 0- absent; 1- < 12 inches; 2- < 36 inches; 3- < 48 inches; 4- < 60 inches; 5- wall / artificial levee

Bank protection conditions: 1- good; 2- slumped; 3- eroded; 4- failed

32. Comments (bank material variation, minor inflows, protection extent, etc.):

26. Some trees along the left bank on levee then grass and a building.

30. The left bank has a levee. The right bank consist of very course material. There appears to be a levee formation along the right bank with fill extending to the narrow flood plain. 
36. Point bar extent: $\underline{\mathbf{2 8 0}}$ feet $\underline{\text { US }}$ (US, UB) to $\underline{\mathbf{1 8 0}}$ feet $\underline{\mathrm{US}}$ (US, UB, DS) positioned $\underline{\mathbf{0}} \%$ LB to $\underline{\mathbf{6 0}} \%$ RB

37. Material: $\mathbf{4 3 5}$

38. Point or side bar comments (Circle Point or Side), Note additional bars, material variation, status, etc.):

Side bar consisting of cobble, gravel, and boulder material

39. Is a cut-bank present? $\mathbf{N}$ ( $Y$ or if $N$ type ctrl-n $c b)$

40. Where? - $(L B$ or $R B)$

41. Mid-bank distance: -

42. Cut bank extent: -

feet -

(US, UB) to feet (US, UB, DS)

43. Bank damage: -

(1- eroded and/or creep; 2- slip failure; 3- block failure)

44. Cut bank comments (eg. additional cut banks, protection condition, etc.):

NO CUT BANKS

45. Is channel scour present? $\mathbf{N}$ ( $Y$ or if $N$ type ctrl-n cs)

47. Scour dimensions: Length -

Width -

Depth :-

46. Mid-scour distance: -

48. Scour comments (eg. additional scour areas, local scouring process, etc.):

NO CHANNEL SCOUR

49. Are there major confluences? $\mathbf{N}$

51. Confluence 1: Distance -

Confluence 2: Distance -

52. Enters on -

Enters on -

54. Confluence comments (eg. confluence name):

NO MAJOR CONFLUENCES
50. How many? -

53. Type(1- perennial; 2- ephemeral)

Type (1-perennial; 2- ephemeral) ( $L B$ or $R B)$

\section{Under Bridge Channel Assessment}

55. Channel restraint (BF)? LB 2

\begin{tabular}{|ccccc}
\hline \multicolumn{2}{|c}{ 56. Height (BF) } & \multicolumn{3}{c}{57 Angle (BF) } \\
LB & RB & LB & RB \\
$\mathbf{3 7 . 5}$ & & & $\mathbf{0 . 5}$ & \\
\hline
\end{tabular}
(1- natural bank; 2- abutment; 3- artificial levee)

58. Bank width (BF) 59. Channel width (Amb) -

61. Material (BF)

LB RB

\begin{tabular}{ll}
2 & 7 \\
\hline
\end{tabular}
62. Erosion (BF)

LB RB

$7 \quad 0$

Bed and bank Material: 0- organics; 1- silt / clay, < 1/16mm; 2- sand, 1/16 - 2mm; 3- gravel, 2 - 64mm; 4- cobble, 64 - 256mm; 5- boulder, > 256mm; 6- bedrock; 7- manmade

Bank Erosion: 0- not evident; 1- light fluvial; 2- moderate fluvial; 3- heavy fluvial / mass wasting

64. Comments (bank material variation, minor inflows, protection extent, etc.):

435 
65. Debris and Ice Is there debris accumulation?

(Yor $N)$ 66. Where? $\mathbf{N}$

(1- Upstream; 2- At bridge; 3- Both)

67. Debris Potential (1-Low; 2- Moderate; 3- High)

68. Capture Efficiency 2

(1-Low; 2- Moderate; 3- High)

69. Is there evidence of ice build-up? 1 (Y or $N)$

Ice Blockage Potential $\mathbf{N}$

(1-Low; 2-Moderate; 3- High)

70. Debris and Ice Comments:

1

67. No debris accumulation near the bridge. The upstream is laterally stable, but has a few cut banks, and some trees leaning into channel.

68. High channel gradient channel and the span length is more than approximately $80 \%$ of the upstream bank width.

\begin{tabular}{|l|c|c|c|c|c|c|c|c|}
\hline Abutments & $\begin{array}{c}\text { 71. Attack } \\
\angle \text { (BF) }\end{array}$ & $\begin{array}{c}\text { 72. Slope } \angle \\
\text { (Qmax) }\end{array}$ & $\begin{array}{c}\text { 73. Toe } \\
\text { loc. (BF) }\end{array}$ & $\begin{array}{c}\text { 74. Scour } \\
\text { Condition }\end{array}$ & $\begin{array}{c}\text { 75. Scour } \\
\text { depth }\end{array}$ & $\begin{array}{c}\text { 76. Exposure } \\
\text { depth }\end{array}$ & 77. Material & 78. Length \\
\hline LABUT & & $\mathbf{0}$ & $\mathbf{9 0}$ & $\mathbf{2}$ & $\mathbf{0}$ & - & - & $\mathbf{9 0 . 0}$ \\
\hline RABUT & $\mathbf{1}$ & $\mathbf{0}$ & $\mathbf{9 0}$ & & & $\mathbf{0}$ & $\mathbf{0}$ & $\mathbf{5 0 . 0}$ \\
\hline
\end{tabular}

Pushed: $L B$ or RB

Toe Location (Loc.): 0- even, 1- set back, 2- protrudes

Scour cond.: 0- not evident; 1- evident (comment); 2- footing exposed; 3-undermined footing; 4- piling exposed; 5- settled; 6- failed

Materials: 1- Concrete; 2- Stone masonry or drywall; 3- steel or metal; 4- wood

79. Abutment comments (eg. undermined penetration, unusual scour processes, debris, etc.):

$-$

1

73. The left abutment protrudes into the channel.

80. Wingwalls:

Exist? Material? Scour Scour Exposure $\begin{aligned} & 81 . \\ & \text { Angle? Length? }\end{aligned}$ Condition? depth? depth?

USLWW:

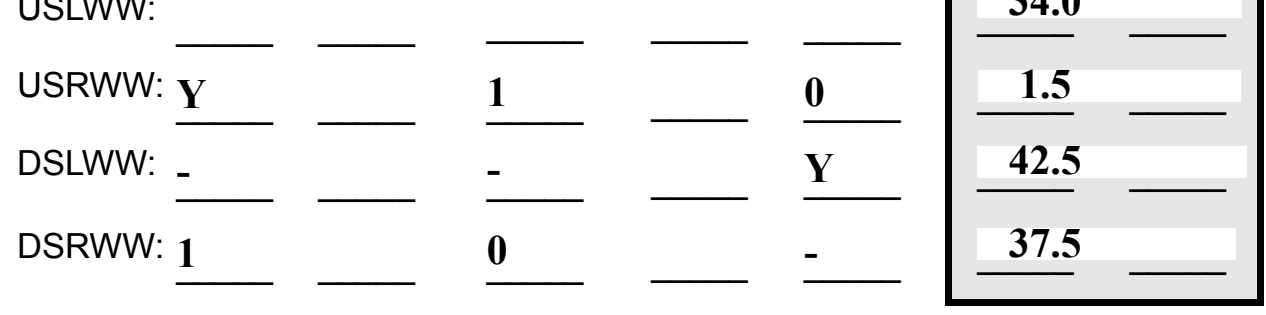

Wingwall materials: 1- Concrete; 2- Stone masonry or drywall; 3- steel or metal; 4- wood

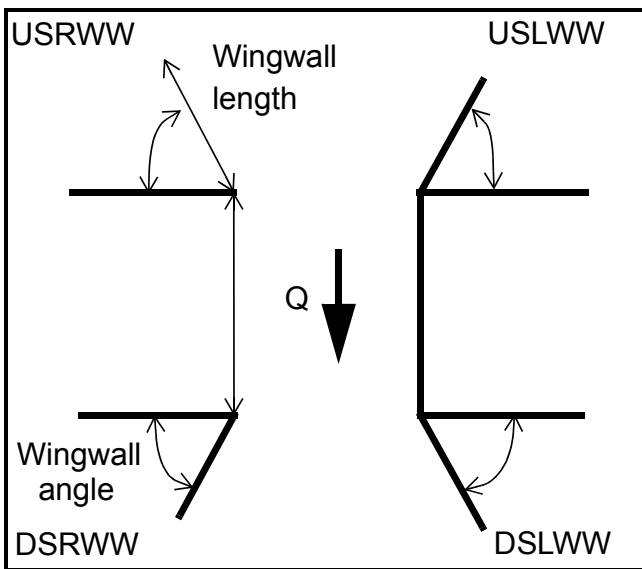

82. Bank / Bridge Protection:

\begin{tabular}{|l|l|l|l|l|l|l|l|c|}
\hline Location & USLWW & USRWW & LABUT & RABUT & LB & RB & DSLWW & DSRWW \\
\hline Type & - & $\mathbf{0}$ & $\mathbf{Y}$ & - & $\mathbf{1}$ & $\mathbf{1}$ & $\mathbf{1}$ & $\mathbf{1}$ \\
\hline Condition & $\mathbf{Y}$ & - & $\mathbf{1}$ & - & $\mathbf{1}$ & $\mathbf{1}$ & $\mathbf{3}$ & $\mathbf{3}$ \\
\hline Extent & $\mathbf{1}$ & - & $\mathbf{0}$ & $\mathbf{2}$ & $\mathbf{3}$ & $\mathbf{3}$ & $\mathbf{3}$ & - \\
\hline
\end{tabular}

Bank / Bridge protection types: 0- absent; 1-<12 inches; 2- < 36 inches; 3- < 48 inches; 4- < 60 inches; 
83. Wingwall and protection comments (eg. undermined penetration, unusual scour processes, etc.):

$-$

$-$

$-$

$-$

$-$

3

1

1

3

1

1

\section{Piers:}

84. Are there piers? $\mathbf{8 2 .}$ ( $Y$ or if $N$ type ctrl-n pr)

\begin{tabular}{|l|l|l|l|l|l|l|l|}
\hline \multirow{2}{*}{$\begin{array}{l}85 . \\
\text { Pier no. }\end{array}$} & \multicolumn{3}{|c|}{ width (w) feet } & \multicolumn{3}{c|}{ elevation (e) feet } \\
\cline { 2 - 8 } & w1 & w2 & w3 & e@w1 & e@w2 & e@w3 \\
\hline Pier 1 & & & & $\mathbf{5 5 . 0}$ & $\mathbf{1 6 . 5}$ & $\mathbf{4 5 . 0}$ \\
\hline Pier 2 & & & $\mathbf{9 . 5}$ & $\mathbf{1 3 . 0}$ & $\mathbf{4 0 . 0}$ & $\mathbf{5 0 . 0}$ \\
\hline Pier 3 & & - & - & $\mathbf{1 1 . 5}$ & - & - \\
\hline Pier 4 & - & - & - & - & - & - \\
Nyyyy
\end{tabular}

\begin{tabular}{|l|l|l|l|l|}
\hline Level 1 Pier Descr. & \multicolumn{1}{|c|}{1} & \multicolumn{1}{|c|}{2} & \multicolumn{1}{|c|}{3} & \multicolumn{1}{|c|}{4} \\
\hline 86. Location (BF) & Upst & end & dow & start \\
\hline 87. Type & ream & is & nstre & s \\
\hline 88. Material & left & bur- & am & abou \\
\hline 89. Shape & wing & ied & end. & t \\
\hline 90. Inclined? & wall & and & At & mid- \\
\hline 91. Attack $\angle$ (BF) & pro- & erodi & the & way \\
\hline 92. Pushed & tec- & ng to & left & to \\
\hline 93. Length (feet) & - & - & - & - \\
\hline 94. \# of piles & tion & almo & abut & the \\
\hline 95. Cross-members & at & st & ment & dow \\
\hline 96. Scour Condition & the & none & large & nstre \\
\hline 97. Scour depth & upst & at & stone & am \\
\hline 98. Exposure depth & ream & the & fill & end; \\
\hline
\end{tabular}

LFP, LTB, LB, MCL, MCM, MCR, RB, RTB, RFP

1- Solid pier, 2-column, 3- bent

1-Wood; 2- concrete; 3- metal; 4- stone

1- Round; 2- Square; 3- Pointed

Y-yes; $N$ - no

$L B$ or $R B$

0- none; 1- laterals; 2- diagonals; 3- both

0- not evident; 1- evident (comment);

2- footing exposed; 3- piling exposed;

4- undermined footing; 5- settled; 6- failed 
99. Pier comments (eg. undermined penetration, protection and protection extent, unusual scour processes, etc.):

smaller cobble/ boulders to upstream end.

At the right abutment large stone fill starts about midway to the downstream end.

DS Left and Right WW: large stone fill starts at the corner junction with the abutment, half way up the wall (smaller grade stones at end).

$\mathbf{N}$

$-$

100.

\section{E. Downstream Channel Assessment}

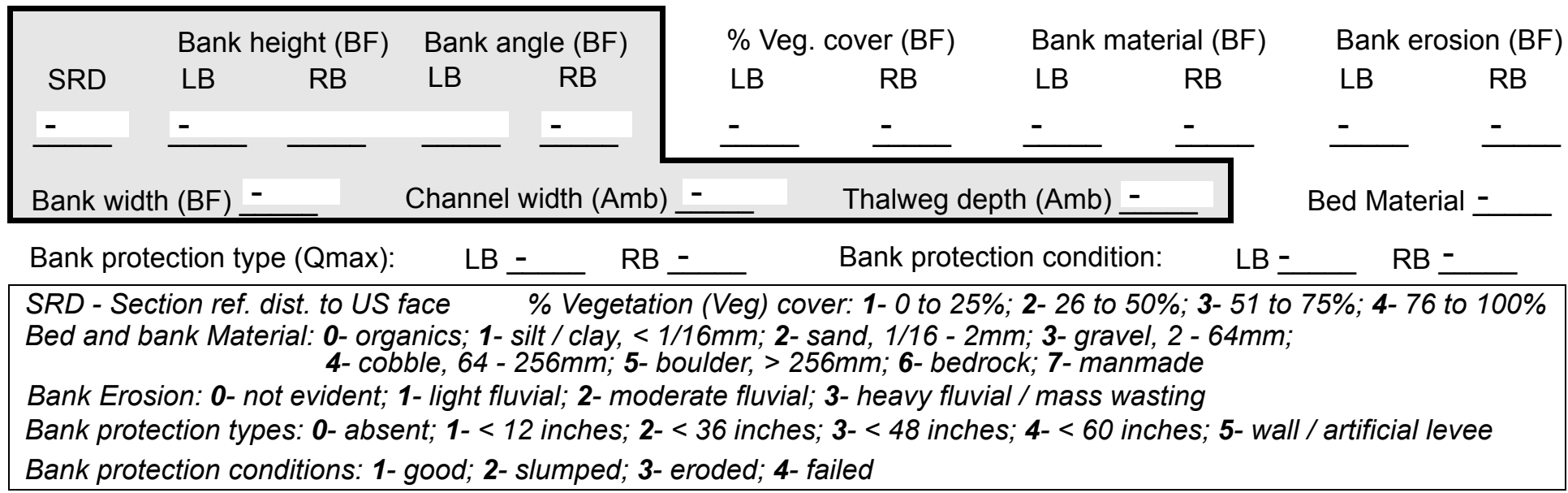

Comments (eg. bank material variation, minor inflows, protection extent, etc.):

$-$

$-$

$-$

$-$

-

-

$-$

-

-

-

\section{Is a drop structure present? __ (Y or N, if N type ctrl-n ds) 102. Distance: _ _ feet}
103. Drop: - feet
104. Structure material: -
(1- steel sheet pile; 2- wood pile; 3- concrete; 4- other)

105. Drop structure comments (eg. downstream scour depth):

-

$-$

-

- 
106. Point/Side bar present? (Y or $N$. if $N$ type ctrl-n pb)Mid-bar distance:

Mid-bar width: -

Point bar extent: feet -

(US, UB, DS) to feet (US, UB, DS) positioned \%LB to $\%$ RB Material:

Point or side bar comments (Circle Point or Side; note additional bars, material variation, status, etc.):

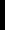

$-$

$-$

\section{NO PIERS}

Is a cut-bank present? ( $Y$ or if $N$ type ctrl- $n$ cb) Where? (LB or $R B)$

Mid-bank distance:

Cut bank extent: feet (US, UB, DS) to feet (US, UB, DS)

Bank damage: (1- eroded and/or creep; 2- slip failure; 3- block failure)

Cut bank comments (eg. additional cut banks, protection condition, etc.):

\section{2 \\ 3}

345

\section{Is channel scour present? 435 (Y or if $N$ type ctrl-n cs) Mid-scour distance: $\underline{\mathbf{0}}$} Scour dimensions: Length Width 345 Depth: 0

Positioned $\underline{0}$ $\%$ LB to $\% R B$

Scour comments (eg. additional scour areas, local scouring process, etc.):

$-$

\section{Are there major confluences?} ( $Y$ or if $N$ type ctrl-n $m c)$

How many?

Confluence 1: Distance Enters on (LB or $R B)$

Type (1-perennial; 2- ephemeral)

Confluence 2: Distance

Enters on (LB or $R B)$

Type (1-perennial; 2- ephemeral)

Confluence comments (eg. confluence name):

\section{F. Geomorphic Channel Assessment}

107. Stage of reach evolution

1- Constructed

2- Stable

3- Aggraded

4- Degraded

5- Laterally unstable

6- Vertically and laterally unstable 
108. Evolution comments (Channel evolution not considering bridge effects; See HEC-20, Figure 1 for geomorphic descriptors):

$\mathbf{N}$

$-$

NO DROP STRUCTURE

$\mathbf{N}$

$-$

$-$

$-$ 


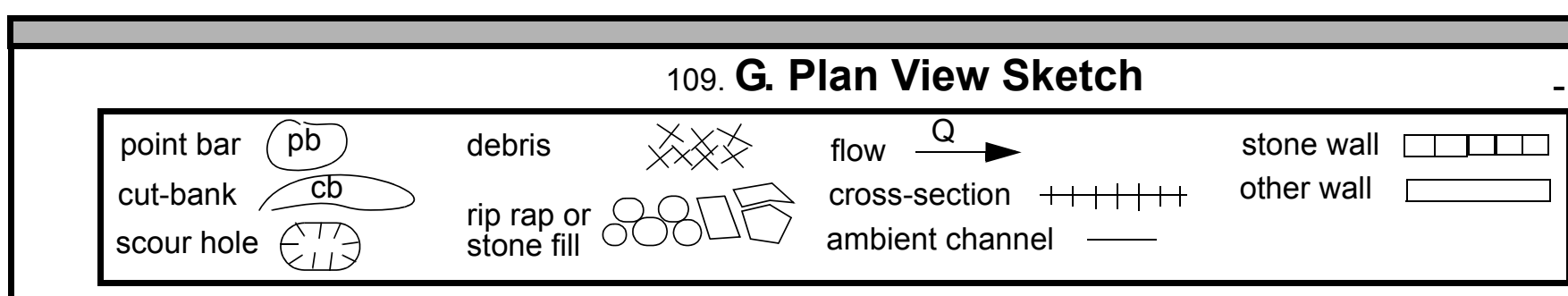


APPENDIX F:

SCOUR COMPUTATIONS 


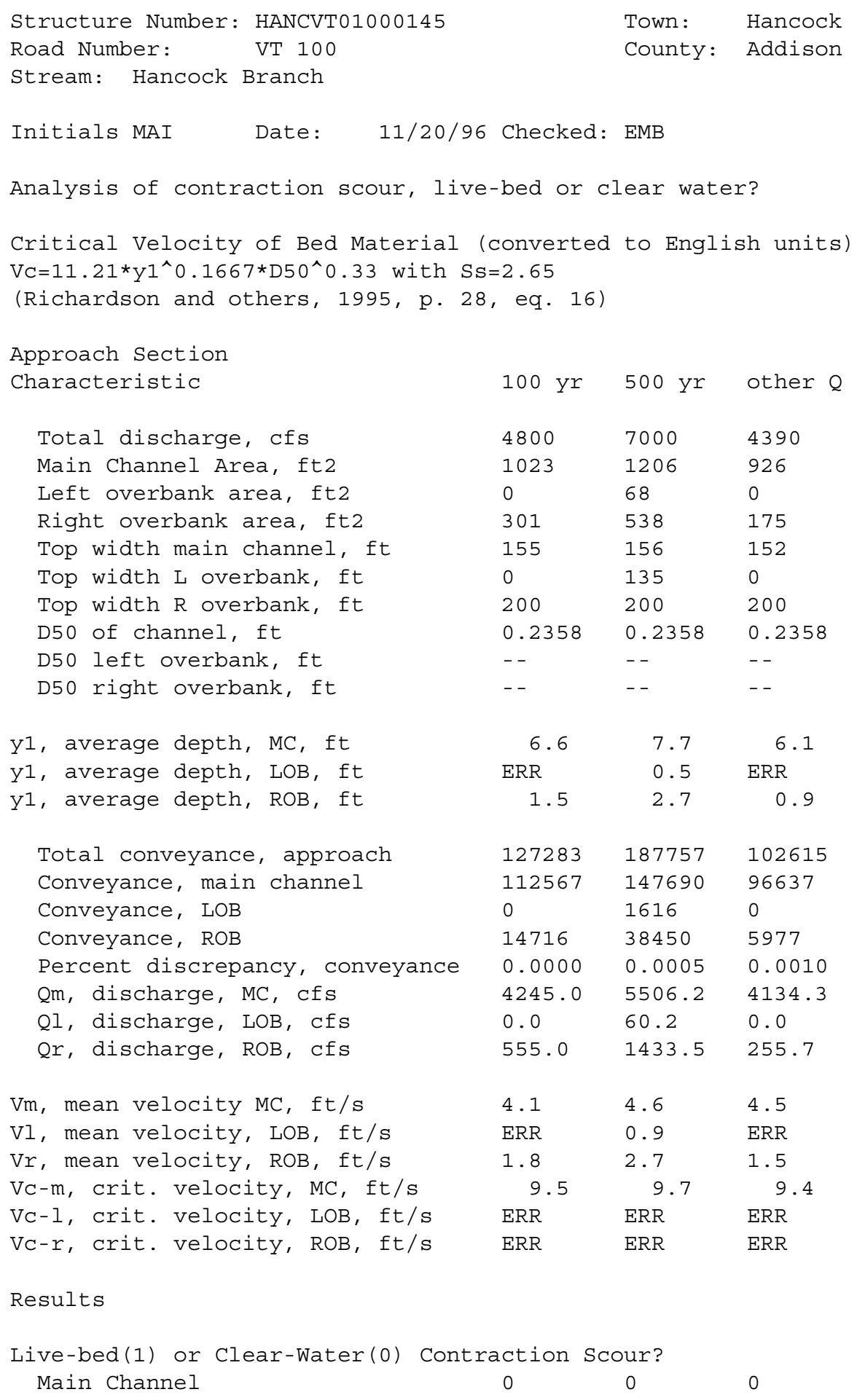


Clear water Contraction Scour in MAIN CHANNEL

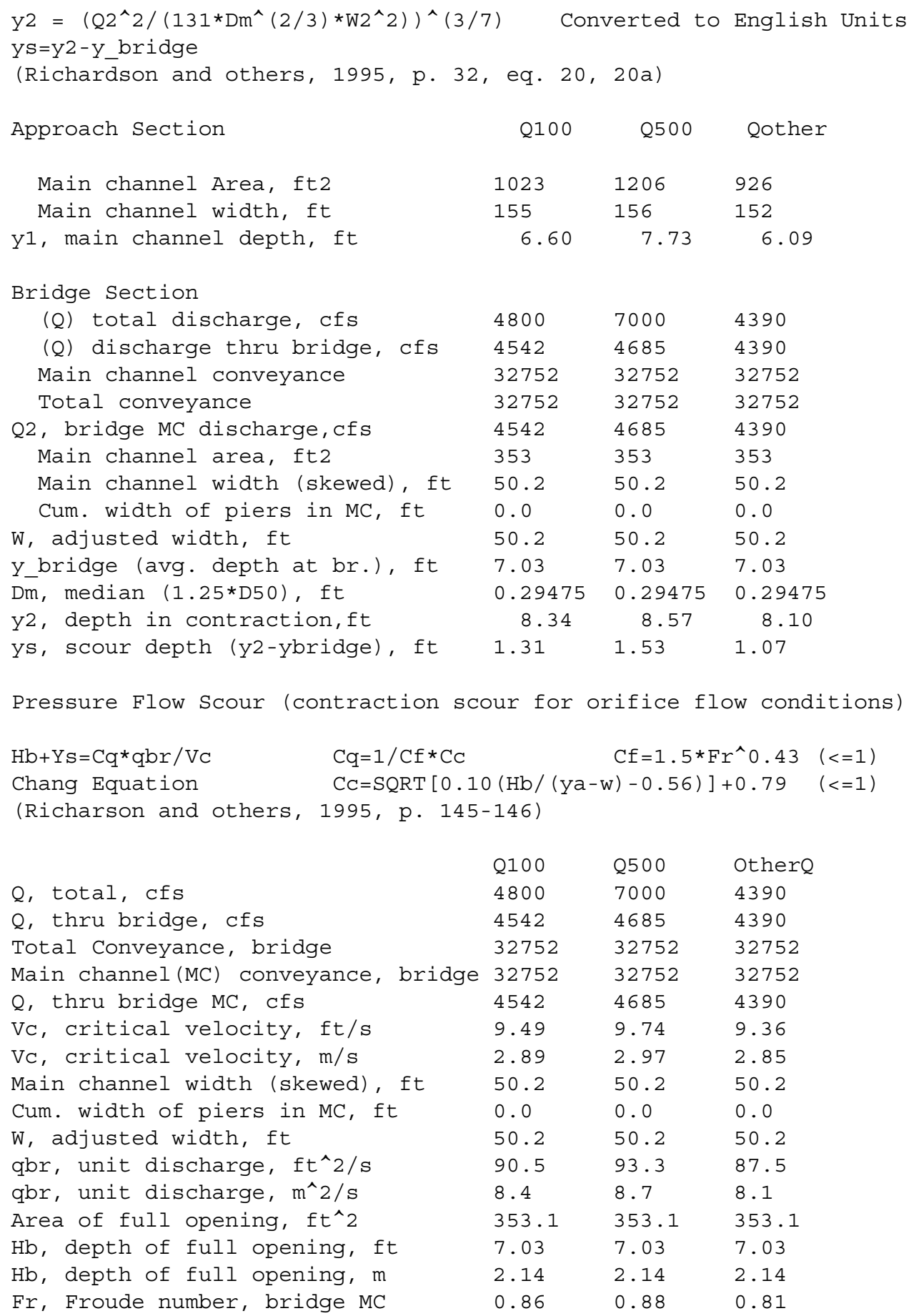




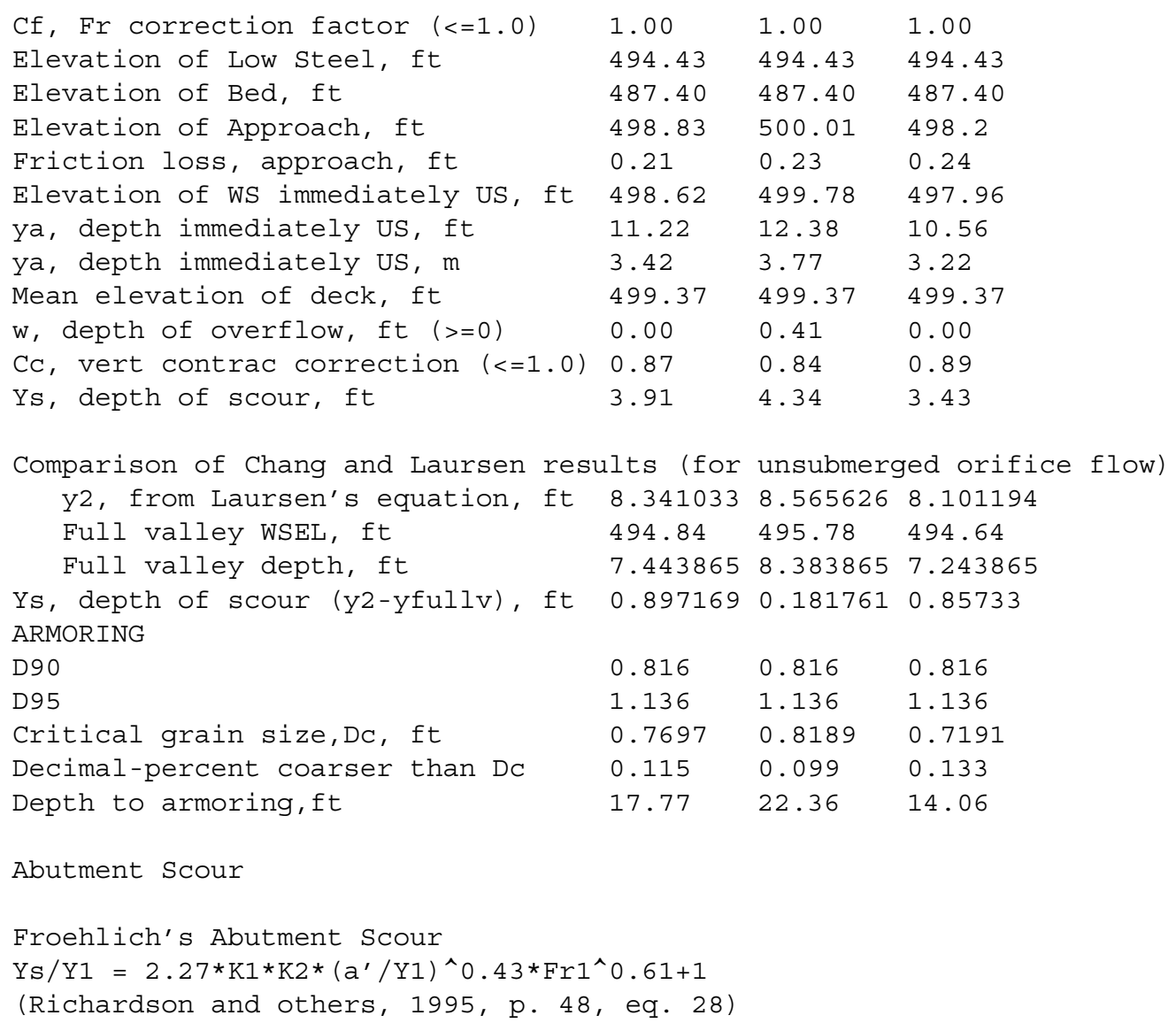




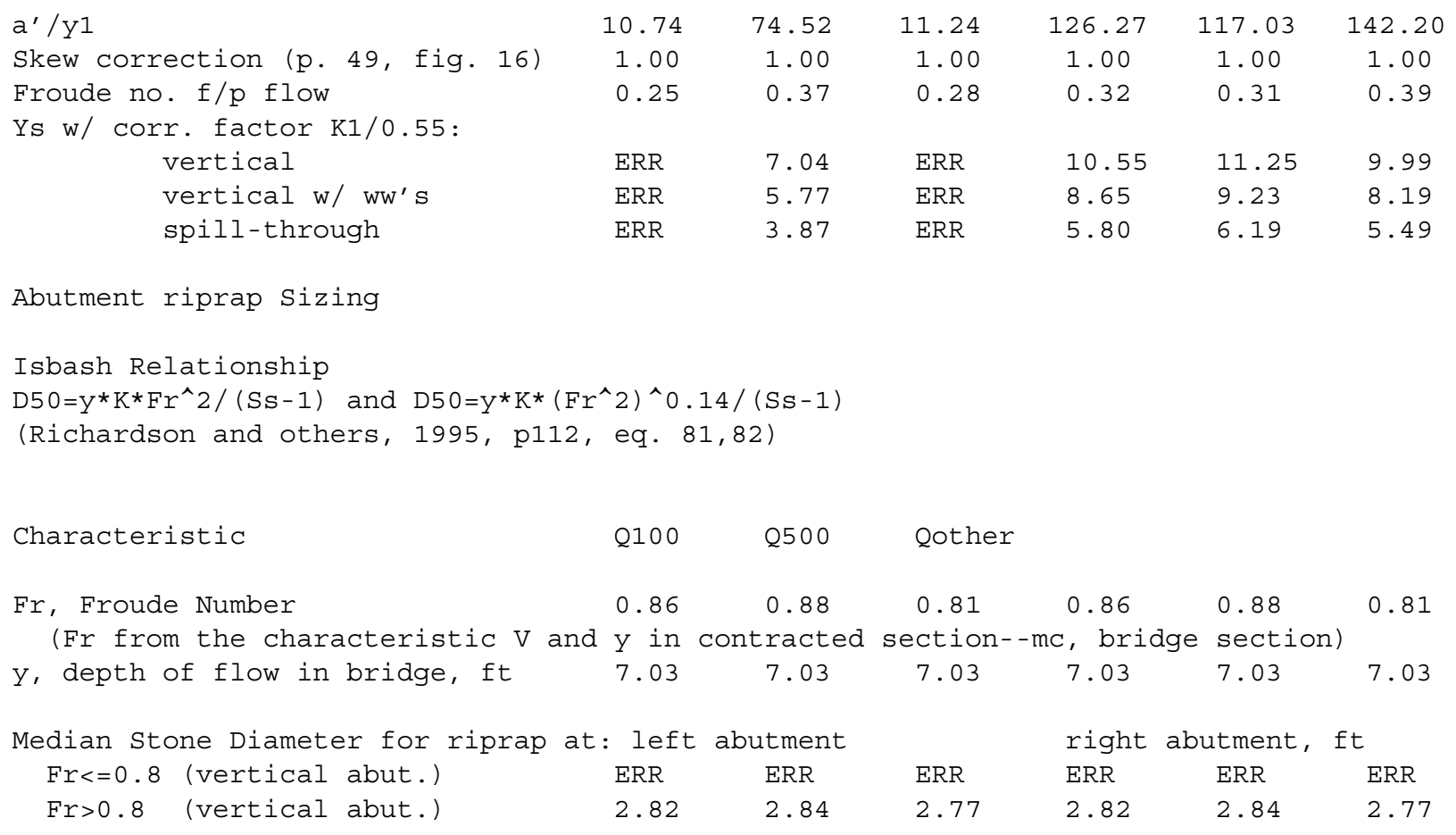

